\title{
THE PERMIAN GYPSUM KARST BELT ALONG THE SOUTHERN MARGIN OF THE HARZ-MOUNTAINS (GERMANY), TECTONIC CONTROL OF REGIONAL GEOLOGY AND KARST-HYDROGEOLOGY
}

\author{
PERMSKI KRAS V SADRI OB JUŽNEM ROBU GOROVJA HARZ \\ (NEMČIJA), VPLIV TEKTONIKE NA REGIONALNO GEOLOGIJO \\ IN KRAŠKO HIDROGEOLOGIJO
}

\author{
Hans-Peter HUBRICH ${ }^{1}$ \& Stephan KEMPE ${ }^{1}$
}

\begin{abstract}
UDC 551.24:551.44(430-17)

Hans-Peter Hubrich \& Stephan Kempe: The Permian gypsum karst belt along the southern margin of the Harz-mountains (Germany), tectonic control of regional geology and karsthydrogeology

The Harz Mountains in Germany are a south-tilting block of variscan-folded Devonian and Carboniferous rocks thrust over Mesozoic sediment along its northern border. Along the South Harz the overlying, unfolded upper-most Carboniferous, Permian and Buntsandstein (lower Triassic) series are exposed in a wide belt. They include a thick series of Upper Permian ("Zechstein") evaporitic rocks, dipping with about $10^{\circ} \mathrm{S}$ to SW, representing a nearly continuous sulfate and carbonate karst area about $90 \mathrm{~km}$ long, covering $338 \mathrm{~km}^{2}$. In his dissertation, the first author compiled a new geological map for the Zechstein at a scale of 1:10,000 and deduced a tectonic model to advance our understanding of the karstic features.

Karstification determines the morphology of the South Harz including over 180 registered caves, thousands of sinkholes, uvalas, sinking creeks and large karstic springs. Specifically, lines of sinkholes appear to follow faults. By detailed mapping of the three lowermost Zechstein cycles, a dense matrix of faults is revealed. $85^{\circ}$ to $125^{\circ}$ striking faults reoccur every few $500 \mathrm{~m}$, formed during the Harz-lifting compressional phase during the Upper Cretaceous. Many of these faults are reverse with a Nward thrust. This leads to repetitive exposure of the strata, causing the broadening of the Zechstein outcrop beyond what would be caused by the dip of the series alone. In other areas, horstand graben-structures are present, resulting in kilometer-long Lower Buntsandstein ridges. Below ground, the groundwater flowing southward along the dip is diverted into the direction of
\end{abstract}

Izvleček

UDK 551.24:551.44(430-17)

Hans-Peter Hubrich in Stephan Kempe: Permski kras v sadri ob južnem robu gorovja Harz (Nemčija), vpliv tektonike na regionalno geologijo in kraško hidrogeologijo

Gorovje Harz v Nemčiji zajema proti jugu nagnjene in v varistični orogenezi nagubane devonijske in karbonske kamnine, ki so na svoji južni meji narinjene na mezozojske sedimente. $\mathrm{Ob}$ južnem delu tega gorovja $\mathrm{v}$ širokem pasu izdanjajo navzgor ležeče nenagubane zgornjekarbonske, permske in spodnjetriasne (Buntsandstein) serije. Te vključujejo debelo zaporedje zgornjepermskih (Zechstein) evaporitnih kamnin, ki vpadajo za približno $10^{\circ}$ proti $\mathrm{J}$ do JZ. To je skoraj kontinuiran sulfatni in karbonatni kraški teren, ki je dolg približno 90 km in se razteza na površini $338 \mathrm{~km}^{2}$. V disertaciji je prvi avtor naredil novo geološko karto Zechsteina v merilu 1 : 10.000 in prikazal tektonski model, s čimer je nadgradil razumevanje kraških pojavov.

Zakrasevanje je značilno za morfologijo južnega Harza in vključuje več kot 180 registriranih jam, tisoč in več vrtač ter uvale, ponore in velike kraške izvire. Kaže se, da nizi vrtač sledijo prelomom. S podrobnim kartiranjem treh najnižjih zechsteinskih ciklov se je razkrila gosta mreža prelomov. Prelomi smeri $85^{\circ}$ do $125^{\circ}$, ki so nastali v zgornji kredi med kompresijsko fazo dviganja Harza, se pojavljajo vsakih nekaj $500 \mathrm{~m}$. Veliko teh prelomov je reverznih prelomov z narivi proti severu. To povzroča, da se vidne plasti ponavljajo in se tako izdanek Zechsteina razširi mnogo bolj, kot le zaradi samega vpada plasti. V drugih delih terena najdemo strukture, kot sta horst in udorina, $\mathrm{v}$ kilometer dolgih spodnjetriasnih Buntsandsteinskih hrbtih. Pod površjem teče podtalnica proti jugu, skladno $\mathrm{z}$ vpadom in $\mathrm{v}$ smeri slemenitve, kar povzroča slemenitvi vzporedne nize depresij, dolin in vrtač. V zadnji fazi

\footnotetext{
${ }^{1}$ Institute of Applied Geosciences, Technical University Darmstadt, Schnittspahnstr. 9, D-64287 Darmstadt, Germany, e-mails: hphubrich@tonline.de; kempe@geo.tu-darmstadt.de
} 
the strike, thus causing strike-parallel depressions, valleys and sinkhole rows. In the final extension phase, faults striking $150^{\circ}$ to $180^{\circ}$ have caused graben-structures, allowing groundwater and surface rivers to flow southward, breaking through the escarpment of the overlying Lower Buntsandstein. Therefore, the tectonic structure of the South Harz determines its hydrology and the karst features apparent at the surface. The tectonic situation of the three largest karstic springs, the Salza Spring at Förste, the Rhume Spring, and the Salza Spring at Nordhausen is discussed along with more shallow karstic settings of the Hainholz/Beierstein, the Trogstein and the area of Hainrode. Key words: Harz Mountains, South-Harz belt, tectonics, Zechstein, Upper Permian, regional geology, karst hydrogeology. ekstenzije so prelomi smeri $150^{\circ}$ do $180^{\circ}$ povzročili strukturne udorine, zaradi česar podtalnica in površinske reke tečejo proti jugu in sekajo strmo pobočje spodnjega Buntsandsteina. Tektonska struktura južnega Harza določa hidrologijo in površinske kraške pojave. Tektonske razmere treh največjih kraških izvirov Salza v Försteju, Rhume in Salza v Nordhausenu so predstavljene skupaj s plitvimi kraškimi pogoji območij Hainholz/Beierstein, Trogstein in Hainrode.

Ključne besede: gorovje Harz, južni pas gorovja Harz, tektonika, Zechstein, zgornji perm, regionalna geologija, kraška hidrogeologija.

\section{INTRODUCTION}

The largest continuous gypsum karst area in all of Germany is the Upper Permian (Zechstein) outcrop along the southern margin of the Harz Mountains (Fig. 1) (Herrmann 1964; Kempe 1996). Stratigraphically the Zechstein, one of the oldest formation names still in use, corresponds internationally to the chronostratigraphic stages of Wuchiapingium and Changhsingium comprising the series of the Lopingium. It lasted from 259.1 to 251.9 Ma ago (International Stratigraphic Table, Cohen et al. 2018). The Zechstein lasted for about $8 \mathrm{Ma}$ (e.g., Menning 1995) and is considered a lithostratigraphic group dominated by evaporites which rests diachronical-

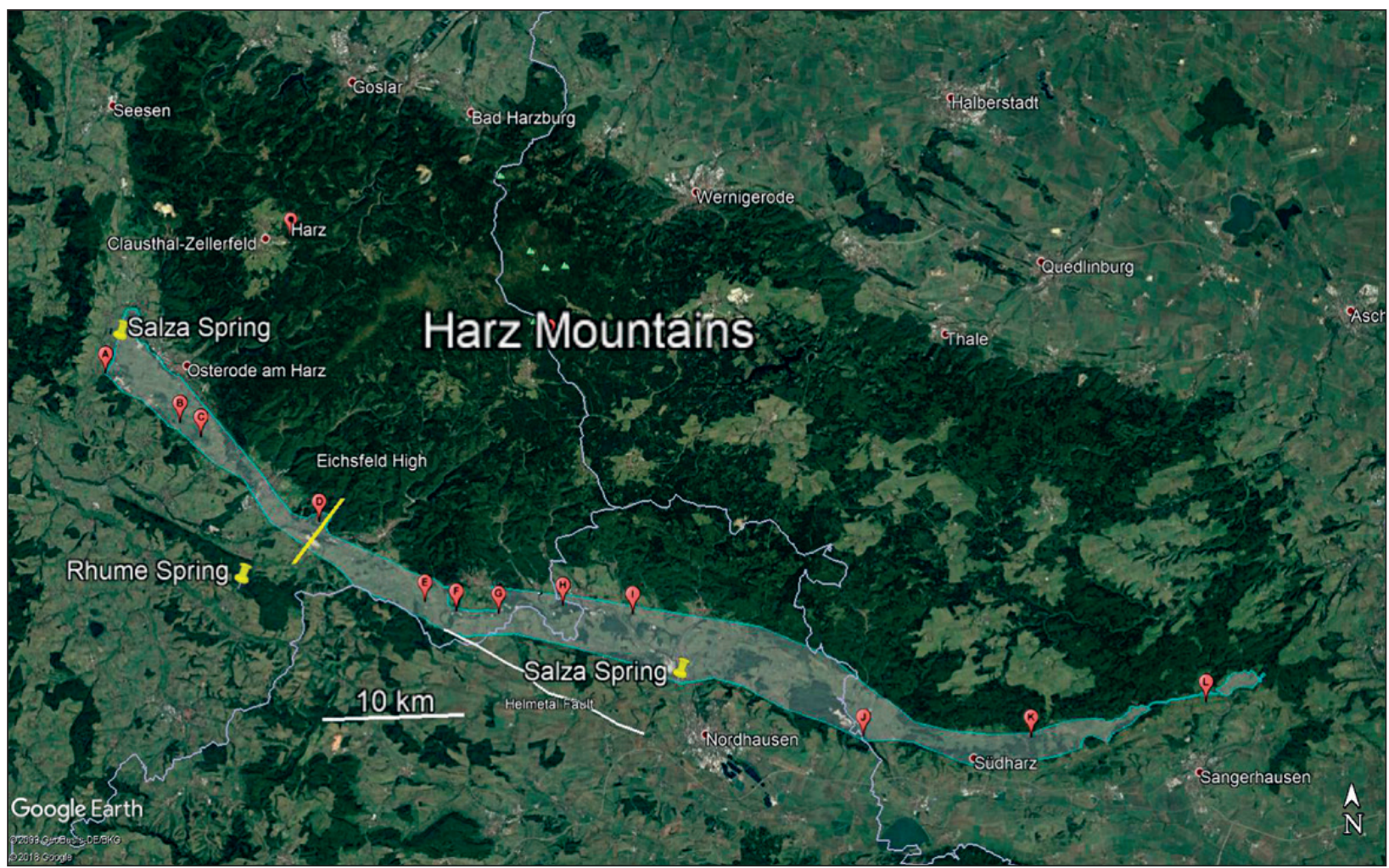

Fig. 1: Google Earth image of the $90 \mathrm{~km}$-long Harz Mountains in Central Germany and its Zechstein-Belt along its southern margin (shaded blue area). Blue lines denote state borders. The three largest karstic spring are pinned (there are-for obvious reasons- two springs of the same name, one in Förste in the west and one near Nordhausen in the east) and the rough location of the Carboniferous High of the "Eichsfeld Schwelle" is indicated. Red pins denote important caves and cave areas (see text for explanation). 
ly on the Rotliegend and is terminated diachronically by the Triassic Lower Buntsandstein. The Zechstein-Basin runs from England through the North Sea, the northern and central part of Germany into Poland (e.g., Scholle et al. 1995). At its center seven salinar cycles were deposited leaving carbonate, sulfate and chloride salts with a thickness of several kilometers. Consecutive burial by Mesozoic rocks lead to the upward movement of halite forming up to $6 \mathrm{~km}$ high salt domes and salt walls below the North Sea and northern Germany. Locally sulfates and carbonates form rare outcrops at the top of these domes (e.g., Segeberg, Luneburg, Elmshorn, Othfresen). Due to the high solubility of chloride salts, none are exposed at the surface within the basin, but salt-bearing springs betray some of the domes. Larger Zechstein outcrops fringe the variscan folded Paleozoic cores of central German mountain ranges. Most of these outcrops occur along the southern margins of the former basin representing near-shore facies of carbonates. Thicker sulfate layers were present further north and the only mountain range that is fringed by appreciable sulfate outcrops is the Harz (Fig. 2). Along its northern side, the Harz tectonic block was thrusted several kilometers above younger Mesozoic rocks, including the Zechstein. It therefore only forms a very narrow band with small local gypsum outcrops. Along the western margin of the Harz, the shoulder of the Gittelde Graben suppresses much of the Zechstein, only thin carbonate beds are preserved above the WHarz Paleozoic. Along the eastern side of the Harz, the Zechstein outcrop is wider but hardly forms any appreciable surface outcrop. This is the Mansfeld Basin that saw intensive mining for copper-shale (Stedingk et al. 2006), the lowest member of the Zechstein, until 1969. Early miners discovered very large, phreatically formed cavities (Freiesleben 1809; who also published the first geological map of the eastern Harz and its surroundings, including the Zechstein), among them the largest anhydrite/gypsum cave of Germany, the Wimmelburger (or Mansfelder) Schlotten (e.g., Stolberg 1943; Brust 2008; Völker \& Völker 1986; Kupetz \& Brust 1991; Kempe 1996; Kempe \& Helbing 2000; Kupetz \& Knolle 2015).

By area, the largest Zechstein anhydrite/gypsum outcrop fringes the southern side of the Harz. It crosses three states from W to E: Lower Saxony, Thuringia and Saxony-Anhalt. The eastern border of Lower Saxony was also the former border between West- and EastGermany, dissecting Harz and South Harz for 40 years and impeding research (Fig. 1). The South Harz is also the largest sulfate karst area of Germany. In the South Harz, the Upper Carboniferous peneplain slopes below post-variscan, unfolded Upper Carboniferous (Mansfelder Schichten), Permian (Rotliegend and Zechstein) and lower Triassic (Buntsandstein) strata which dip with about $5^{\circ}$ to $10^{\circ}$ south. The belt is over $90 \mathrm{~km}$ long with a width that varies from a few hundred meters in the east to about $5 \mathrm{~km}$ in the center near Nordhausen and 3 to $5 \mathrm{~km}$ in the west around Osterode. In the east, coppershale was mined in the Sangerhausen Basin until August 1990. The South Harz also contains the most important German gypsum caves that are accessible from the surface (e.g., Kempe 1996) and gives rise to a series of large karstic springs (Fig. 1). Over 180 caves have been documented. It is of note that caves do not occur statistically distributed but are clustered in certain areas. Labels in Fig. 1 show locations of the most important caves and cave areas: A) Lichtenstein, B) Beierstein (Klinkerbrunnen), C) Hainholz (Jettenhöhle, Marthahöhle), D) Einhornhöhle, Steinkirche, E) Weingartenloch F) TrogsteinFitzmühlen System, G) Priester- and Sachsenstein, H) Himmelreich, I) Kelle, J) Heimkehle, K) Questenberg, L) Schlotten discovered during copper-shale mining. Apart from the very ancient caves in Dolomite (Fig. 1: D; e.g., Vladi 2004) most caves in gypsum are apparently of young age (Kempe 1982). Two groups of caves can be discerned: (i) caves associated with sinking creeks (A, F, $\mathrm{H}$, J in parts, $\mathrm{K}$ in parts) while (ii) the other caves are mostly caused by phreatic, slow convective water movement (B, C, I, J mostly, L; e.g., Biese 1931; Kempe 1982; Brandt et al. 1976; Kempe 2014). Schlotten, i.e. caves at or below the ground water level were also discovered by mining for copper-shale at a number of places (Völker \& Völker 2017). Two of them (Brust \& Graf 2016), are still accessible, the Elisabethschächter Schlotte (Völker \& Völker ca. 1982, 1984) and the Segen Gottes Schlotte (Völker \& Völker 1983). Thus, karstification and speleogenesis depends on local availability of water, either from the surface (epigenetically) or from the underlying strata (hypogenically) or from both. In case of the Hainholz, the first detailed geological mapping of the area by Kempe, Seeger and Vladi (Kempe et al. 1970; repeated in part by Herrmann 1981a), showed that the area is tectonically structured, forming a graben. These faults bracketing the karst area - are responsible both for sinks as well as springs, clear hints that the tectonic structure of the Zechstein plays a decisive role in explaining the occurrence and distribution of karstic features and their hydrogeological predisposition.

Another riddle had to be solved that was not addressed adequately by previous researchers and that is the problem of the varying outcrop widths. With a steady dip towards the south, the width of the outcropping $90 \mathrm{~km}$ long Zechstein Belt should amount to about a kilometer depending on the thickness of the strata. Most previous maps of the Zechstein lack faults, for example the latest one published, the geological Quadrant 4227, Osterode (Jordan 1976). The geological profile accompanying the 


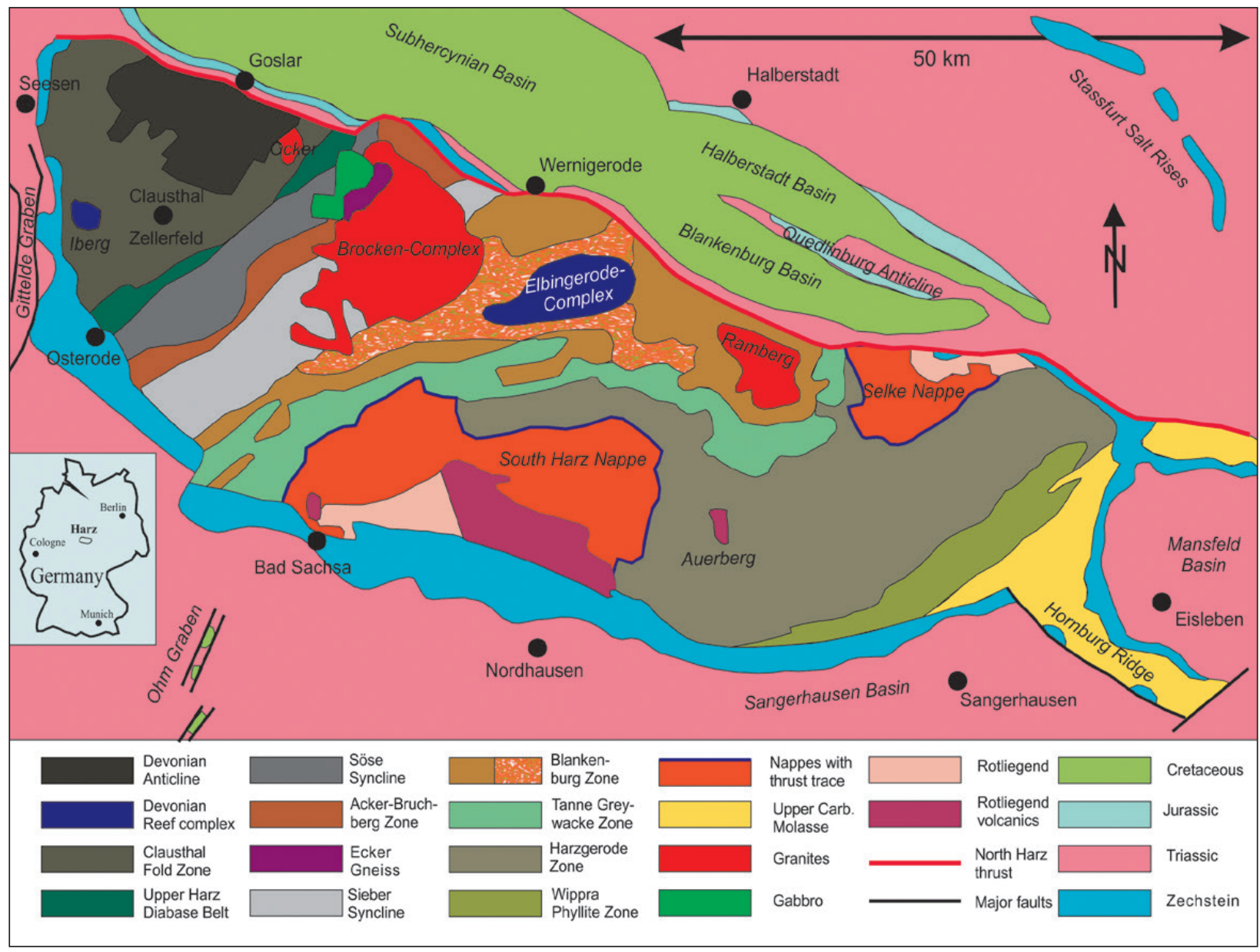

Fig. 2: Geological overview of the Harz Mountains and surroundings; Harz units not marked Devonian are predominantly Carboniferous (altered after Geologische Karte Harz 1: 100,000, Geol. Landesamt Sachsen-Anhalt, 1998).

map shows how faults are avoided: where the Zechstein rests unconformably on the folded variscan rocks of the Harz, it dips south with about $10^{\circ}$ but then, after about $1 \mathrm{~km}$ to the west the dip in the profile is reduced to $4^{\circ}$. At about $2 \mathrm{~km}$ into the profile the basis of the Zechstein should be $250 \mathrm{~m}$, i.e. the maximal thickness of the Werra anhydrite, below ground. However, here a borehole shows that the variscan rocks were reached at a depth of only $125 \mathrm{~m}$ below the surface. With an assumed total thickness of $440 \mathrm{~m}$ the Zechstein strata should dip below the Buntsandstein $2.5 \mathrm{~km}$ into the profile, i.e. at about the location where the white gypsum cliffs rise north of Osterode. Faults of about $480 \mathrm{~m}$ uplift would be needed to maintain the steady dip of the Zechstein basis. In Jordan (1976), there is no discussion about this discrepancy and there is no explanation why the presence of faults is dismissed. It is simply assumed that the dip of the Zechstein basis is diminishing southward. This assumption is also used in many other profiles in the literature. In case of the profile on Quadrant 4227, faults would have the advantage of explaining why the river that runs across the profile, the Söse, is deflected from its NE-SW course when leaving the Harz to a SENW course. Faults in this direction are numerous in the folded Paleozoic on the same geological Quadrant. These faults are in parallel to the thrust-fault that uplifted the Harz in the north, striking NW-SE, a direction that bears the name "hercynian" in German tectonics (i.e., lat. "Hercynia" for "Harz"). Why would the Zechstein not show faults of this direction?

One further problem is associated with the nine geological 1:25,000 Quadrants representing the South Harz Zechstein: some of them are more than a hundred years old and at the time the cyclic nature of the Zechstein (e.g., Richter-Bernburg 1955) was not properly understood. The gypsum layers were differentiated into older and younger strata, while there are three cycles present that can be differentiated in mapping: The Werra, Stassfurt and Leine Cycles (sometimes the thinly developed Aller Cycle is present as well). The upper three 
cycles are only present in deeper parts of the NorthGerman basin (the Ohre, Friesland and Fulda Cycles).

Because the former "iron curtain" - the border between West- (BRD) and East-Germany (DDR) - divided the Zechstein belt there is no unified view of the regional geology of this important karst area. Only sections of the belt were dealt with in the west by Herrmann (1956), Jordan (1979) and Kulick \& Paul (1987). WilliamsStroud \& Paul (1997) and Paul $(2014,2016)$ repeatedly advanced the hypothesis, that recurrent outcrops of gypsum are "gypsum piercement structures", i.e. gypsum ridges formed by diapiric rising driven by porewater and dehydration water release early in the diagenetic processes and during the formation of anhydrite. This process, if operating at all, would, however, not increase the entire thickness of the respective sulfate formation, since it would conserve initial sulfate mass. It would not solve the problem of varying outcrop width of the Zechstein Belt. It would only add to the complexity of the internal structure of the gypsum/anhydrite strata that is partly characterized by subaquatic slides causing synsedimentary intra-strata folding (e.g., Herrmann \& Richter-Bernburg 1955).

In East-Germany geological mapping was hindered by the vicinity to the heavily guarded and fortified border, by limited funds and differently structured university courses. However, cave exploration and the study of old mining documents did add considerable information. It was made available through a series of booklets published by the Karst Museum at the Heimkehle near Uftrungen (Völker 1981) and authored by Christel and Reiner Völker (compare Völker \& Völker 1986 and recently Völker \& Völker 2019). The research and documentation that accompanied the mining for coppershale was also important, concerning stratigraphy and tectonics of the Sangerhausen Basin or the Thuringian Basin (Seidel 1974). After German reunification in 1989 Paul et al. (1998) published a newly surveyed section of the gypsum karst near Stempeda.

The mentioned tectonic and stratigraphic ambiguities and the positive results obtained during the Hainholz mapping in 1970 (Kempe et al. 1970) and the following hydrogeochemical surveys (Brandt et al. 1976; Kempe 1982) spawned the idea to remap the entire Zechstein Belt and to analyze it in view of the general tectonics of Central Germany as well as to advance our understanding of karstic springs and karst water courses. Since 1986 (beginning in Förste in the west and progressing eastward to Morungen) nearly the entire area of the $338 \mathrm{~km}^{2}$ of the Zechstein Belt was re-mapped during diploma theses and university mapping courses supervised and conducted by the second author. This was the basis of the doctoral thesis of the first author who had the task to unite all maps into one new Zechstein map and to develop a tectonic model that could explain the open questions and integrate the South Harz into the general tectonic evolution of the Harz and Central Europe.

\section{GEOLOGICAL SITUATION}

After the variscan orogeny along NE-SW fold axes and the peneplanation of its mountains in the Upper Carboniferous, Central Europe was exposed to stress fields that first caused (i) extension and widespread basin formation, followed (ii) by strong compression and uplift, succeeded (iii) again by dilatation. Formerly these processes were summarized as "Saxonic Tectonism" but should better be called "inversion tectonics" (e.g., Kley 2013). The basins that formed in the first extension accommodated both marine and terrestrial sediments several kilometers thick up to the Upper Cretaceous. The consecutive compression resulted from the stress field between Iberia-Briançonnais and Baltica (Kley \& Voigt 2008: 841) and resulted in widespread uplift. The recent stress is associated with the opening of the Atlantic leading to rhenian striking graben structures. These stresses resulted in open folding, faulting, overthrusting and jointing of the rocks. There are several general directions of these tectonic elements that are common in Central Europe (Carlé 1955):

\begin{tabular}{|c|c|c|}
\hline NNE - SSW & rhenian & $0-10^{\circ}$ \\
\hline NE - SW & $\begin{array}{c}\text { erzgebirgian - } \\
\text { variscan }\end{array}$ & $40^{\circ}-60^{\circ}, 70^{\circ}$ partly \\
\hline WNW-ESE & hercynian & large range $85^{\circ}-125^{\circ}$ \\
\hline NNW-SSE & eggian & $150^{\circ}$ \\
\hline
\end{tabular}

The compression (ii) led to the uplift of southward dipping blocks of variscan folded series along steeply northward inclined thrust faults striking NW-SE such as the Harz Mountains, about $90 \mathrm{~km}$ long NW-SE and $30 \mathrm{~km}$ wide. The Harz exposes mostly Devonian and Carboniferous slate, greywacke and volcanics (Fig. 2). Along its northern border the range was thrusted over the Upper Cretaceous series in several pulses along faults striking hercynian NW-SE (e.g., "wrench-faulting"; Wrede 1979, 
1988). The consecutive extension (iii) of Europe led to extensive graben systems. One of them is the NNE-SSW striking Upper-Rhine-Graben, the origin for the "rhenian" direction in Central Europe. Hercynian and rhenian faults and joints dominate the tectonics in Central Europe and are clearly seen as determining the direction of many cave passages and groundwater flow.

The Harz block slopes southward and dips below the unfolded post-Carboniferous strata. From east to west the transgression across the variscan rocks is first by upper Carboniferous clastics (Mansfelder Schichten), then by clastics of the Rotliegend (lower Permian) and then by the Zechstein itself. Its transgression must have been rather fast since it left a gravelly, calcareous, i.e. marine, conglomerate and apparently covered the entire area of the modern Harz with an at least $100 \mathrm{~m}$ deep anaerobic basin. Ocean water intruded from the NE across shallow sills. The first marine layer was a laminated black marl, rich in organics and sulfidic ores, the "copper-shale" with its famous fish-fossils like the ganoid-scaled Palaeoniscum freieslebeni (e.g., Kuhn 1964). This layer -often less than $30 \mathrm{~cm}$ thick- was mined since Bronze Age. Situated at the tropics, the intracontinental sea became hypersaline with high evaporation rates. As the Zechstein Basin subsided further, four cycles of clay, carbonate-, sulfate- and chloride-salts were deposited in the region (Table 1): The Werra, Stassfurt, Leine and Aller Cycles. The total thickness of the series is difficult to assess because today the salt layers are missing, the anhydrite turned near-surface into gypsum with a gain in volume of $26 \%$, and gypsum is also dissolved quickly: The Hainholz hydrological data allowed to calculate this loss to about $4 \mathrm{~m} / 10,000$ a (Kempe \& Emeis 1979). Dissolution of gypsum proceeds both from below by water advected through the underlying carbonate strata and from above by precipitation (Brandt et al. 1976). Where the gypsum has been dissolved, marly, carbonate-clasts bearing residual sediments form (Rauhwacken). Due to the dissolution of salt and gypsum, much of the sediment column above the Werra sulfate is broken and collapsed, making it difficult, if not impossible, to obtain correct dip and strike measurements.

Due to the dissolution of the salt before the Zechstein is exposed - followed by the dissolution of the gypsum - thickness of layers are difficult to assess. For example, the boreholes north of Osterode (Katzenstein, Petershütte), mentioned above, reach the z1K (Zechsteinkalk) at depths of 98, 125.4 and $124 \mathrm{~m}$ (Jordan 1976: 134). These depths are added to the height of the gypsum escarpment of $100 \mathrm{~m}$ west of the well sites. Thus, a minimum thickness of the $\mathbf{z 1} \mathbf{A}$ (WerraAnhydrite) of $225 \mathrm{~m}$ is obtained. Allowing for some loss by surface dissolution the maximal thickness is given as $250 \mathrm{~m}$. Such a calculation seems to be straightforward but does not allow for the possibility of faults below the Söse River. If considering this possibility, the actual z1 A thickness could be much less, amounting to 100-150 m only. The first two boreholes are only $150 \mathrm{~m}$ apart in a

Tab. 1: Stratigraphy of the outcropping strata of the South Harz Zechstein Belt (Herrmann 1956, 1981b).

\begin{tabular}{|c|c|c|c|c|}
\hline Signature * & Stratigraphy (German Formation Names) & Thickness & & Cycles \\
\hline su & Lower Buntsandstein (including Bröckelschiefer) & $>200 \mathrm{~m}$ & & Triassic \\
\hline $\mathrm{Z} 4 \mathrm{~A}$ & Aller-anhydrite & $<2 \mathrm{~m}$ & \multirow{12}{*}{ 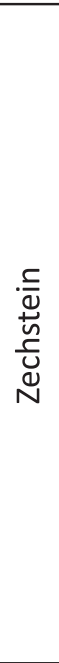 } & \multirow{2}{*}{ Aller-Cycle } \\
\hline Z4T & Red salt-clay (roter Salzton) & $8-10 m$ & & \\
\hline $\mathrm{Z3A}$ & Leine-anhydrite (Hauptanhydrit) & $35-70 m$ & & \multirow{3}{*}{ Leine-Cycle } \\
\hline z3K & Leine-carbonate (Plattendolomit) & $2-25 m$ & & \\
\hline z3T & Gray salt-clay (Grauer Salzton) & $3-10 m$ & & \\
\hline $\mathrm{Z} 2 \mathrm{~A}$ & $\begin{array}{l}\text { Stassfurt-anhydrite } \\
\text { (Sangerhausen-Anhydrit and Basal-Anhydrit) }\end{array}$ & $0-30 \mathrm{~m}$ & & \multirow{3}{*}{ Stassfurt-Cycle } \\
\hline $\mathrm{z} 2 \mathrm{~K}$ & Stassfurt-carbonate (Stinkkarbonat, Stinkschiefer) & $0-60 m$ & & \\
\hline $\mathrm{z} 2 \mathrm{~T}$ & Brown-red salt-clay (Roter Salzton) & $0-2 m$ & & \\
\hline $\mathrm{z} 1 \mathrm{~A}$ & Werra-anhydrite & $0-250 m$ & & \multirow{4}{*}{ Werra-Cycle } \\
\hline $\mathrm{z} 1 \mathrm{~K}$ & Werra-carbonate (Zechsteinkalk) & $0-10 \mathrm{~m}$ & & \\
\hline z1T & Copper-shale (Kupferschiefer) & $0-0,5 \mathrm{~m}$ & & \\
\hline $\mathrm{z} 1 \mathrm{C}$ & Zechstein-conglomerate & $0-3 m$ & & \\
\hline$c / d$ & $\begin{array}{l}\text { Discordance: } \\
\text { Rotliegend, Upper Carboniferous and Devon }\end{array}$ & & \multicolumn{2}{|r|}{ Pre-Zechstein } \\
\hline
\end{tabular}

*Signatures according to symbol key of LBEG (11/2002) 


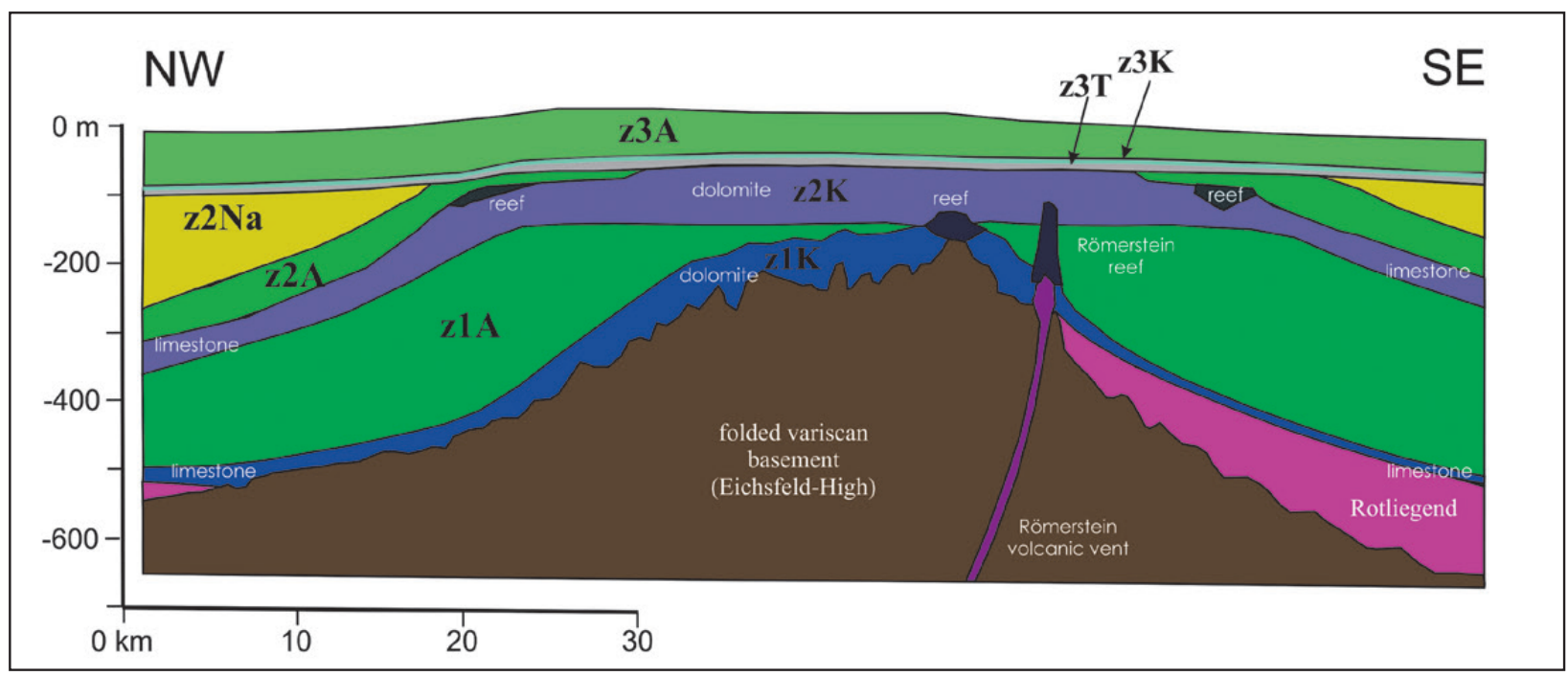

Fig. 3: Much exaggerated schematic NW-SE profile across the Eichsfeld-High, (altered after Paul 1987). For stratigraphic abbreviations see Tab. 1.

N-S direction. If there were no faults, they should have reached the $\mathbf{z} 1 \mathrm{~K}$ at roughly the same depth, but this is clearly not the case. Thus, doubt exists that an approach dismissing faults is geologically correct when calculating strata thicknesses.

The situation is better for the Quadrant 4523 of Kelbra in the east (Schriel \& Bülow 1926). Here ten boreholes were sunk to explore for copper-shale. All of them stood in the Lower Buntsandstein and penetrated the entire Zechstein. Some encountered salt, both the z1Na which is 5 to $6 \mathrm{~m}$ tick and the $\mathbf{z} 2 \mathrm{Na}$ preserved in Well 3 with over $100 \mathrm{~m}$ thickness (it is up to $600 \mathrm{~m}$ thick in the central basins). Gypsum dissolution should not have occurred to any extent. The average Zechstein thickness without salt was $161 \mathrm{~m}$ ( $\min 130 \mathrm{~m}$, max 182 $\mathrm{m}$ ). The calculated inclination of strata is $7^{\circ}$ (Schriel \& Bülow 1926:39).

One more complexity has to be considered and that is thickness and facies changes across the Eichsfeld-High (Fig. 1) (Herrmann 1956, 1969a; Priesnitz 1969a; Paul 1987). Fig. 3 gives a rough scheme of the function of this paleogeographical ridge (note that thicknesses are depending on the total depth of the basin, which is unknown). During the Werra Cycle water depth on the Eichsfeld-High was shallow so that dolomite ("Hauptdolomit") precipitated instead of $\mathbf{z 1 K}$ ("Zechsteinkalk") and z1A (Werra-Anhydrite). Stromatolite reefs like the "Römersteine" and the "Westernsteine" grew on hardgrounds (Paul 1987; Röhling 2004). Gypsum precipitated from the extremely heated water column above the rise but was transported as fine-grained mud by wave action to the flanks of the rise. There it formed thick layers that show internal slumping due to the steep slopes. Similarly, the $\mathbf{z 2 K}$ is much thicker and dolomitic on top of the rise than its layers in the basin. Neither $\mathbf{z 1} \mathbf{A}$ nor $\mathbf{z 2 A}$ were therefore deposited on top of the Eichsfeld-High. During the Leine Cycle the High was finally flooded and the $\mathbf{z 3 T}, \mathbf{z 2 K}$ and $\mathbf{z 3 A}$ were deposited across it as well as z3Na (not shown).

\section{METHODS}

The east-west division of Germany prohibited a comprehensive and unified approach to the South Harz, its stratigraphy and tectonic. Of the nine 1:25,000 Quadrants concerned with the Zechstein Belt, only sheet 4227 has been re-edited (Jordan 1976), while most of the Quadrants are about 100 years old, some of them originating from the late $19^{\text {th }}$ century. In 1986, the second author started a long-term project to map the
Zechstein Belt at a scale of 1:10,000 within the diploma course (equivalent to MSc courses) requirements at the Geological and Paleontological Institute of the University of Hamburg with the last section assigned at Walkenried in 1989. In the same year the fall of the wall in Germany opened the possibility to continue mapping eastward. After 1994, when the second author changed to the Technical University of Darmstadt (Institute of 
Applied Geosciences), mapping was continued during basic and advanced mapping courses and as bachelor theses. Overall, about 40 theses were supervised that mapped Zechstein areas. This material, plus the published geological maps plus additional field work, lists of wells and of sinkholes are summarized in the current $\mathrm{PhD}$ thesis of the first author. Sinkhole maps and locations were kindly made available by the Ing. Office Völker, Uftrungen. Information on mapping techniques and the maps used and their authors are found in the thesis (Hubrich 2020).

All maps were scanned and entered in ArcGIS ${ }^{\mathrm{TM}}$ and georeferenced. Different layers contain the geographical maps, the published geological Quadrants, the diploma theses maps, the mapping course results, sinkhole maps and other information. The georeferencing allows to calculate areas and lengths and to conduct statistical analyses. The aim was to create one consistent geological map, from which a map without Quaternary was to be deduced which in turn would be the basis to analyze tectonics. Quaternary deposits are widespread in the area: Harz river terraces, glacial loess and loess loam, remains of Elsterian moraines (characterized by Baltic Cretaceous flints and Scandinavian erratics) as well as periglacial solifluction blankets covering together $158 \mathrm{~km}^{2}$ (of which $12 \mathrm{~km}^{2}$ are solifluction areas) or $43 \%$ of the $338 \mathrm{~km}^{2}$ of Zechstein. The areas of the $\mathrm{z} 1 \mathrm{~A}$, $\mathrm{z} 2 \mathrm{~A}, \mathrm{z} 3 \mathrm{~A}, \mathrm{z} 1 \mathrm{~K}, \mathrm{z} 2 \mathrm{~K}$ and $\mathrm{z} 3 \mathrm{~K}$ amount to $31,11,12,20,83$ and $5 \mathrm{~km}^{2}$, respectively.

To derive at a plausible tectonic model the geological maps were used to construct 150 down-dip geological profiles every $500 \mathrm{~m}$ from west to east. To do so, the regional dip is needed. It can only be measured reliably for the well-bedded $\mathbf{z 1 K}$, the Zechsteinkalk, because it is not affected by dissolution of layers below it. All other formations rarely give a reliable dip figure because of the possibility of subaqueous slip or dissolution of layers below (salt, gypsum). However, even this "mapping rule" is ambiguous since the $\mathbf{z} \mathbf{1 K}$ was deposited onto the Carboniferous and Lower Permian paleomorphology displaying a landscape with low hills and ridges, incised by valleys. Tab. 2 lists all $\mathbf{z 1 K}$ dip measurements used in the diploma theses. The weighted average (using $4^{\circ}$ for the first group and $19^{\circ}$ for the last group and average mean values for the other groups) gives an average dip of $10.6^{\circ}$. The general dip of the Zechstein southward was also revealed by the copper shale mining in the Sangerhausen Basin (Fig. 4).

Tab. 2: Statistics of measured $\boldsymbol{z 1 K}$ dip.

\begin{tabular}{|c|c|c|}
\hline Dip $\left(^{\circ}\right)$ & N of cases & in \% \\
\hline $0-4$ & 13 & 20 \\
\hline $5-9$ & 12 & 19 \\
\hline $10-14$ & 26 & 41 \\
\hline $15-19$ & 7 & 11 \\
\hline$>19$ & 6 & 9 \\
\hline Sum & 64 & 100 \\
\hline
\end{tabular}

Morphology was taken from the topographical Quadrants. Constructing the profiles was an iterative process, similar to the task to solve equations with too many unknowns: Dip angle, thickness of layers, dis-

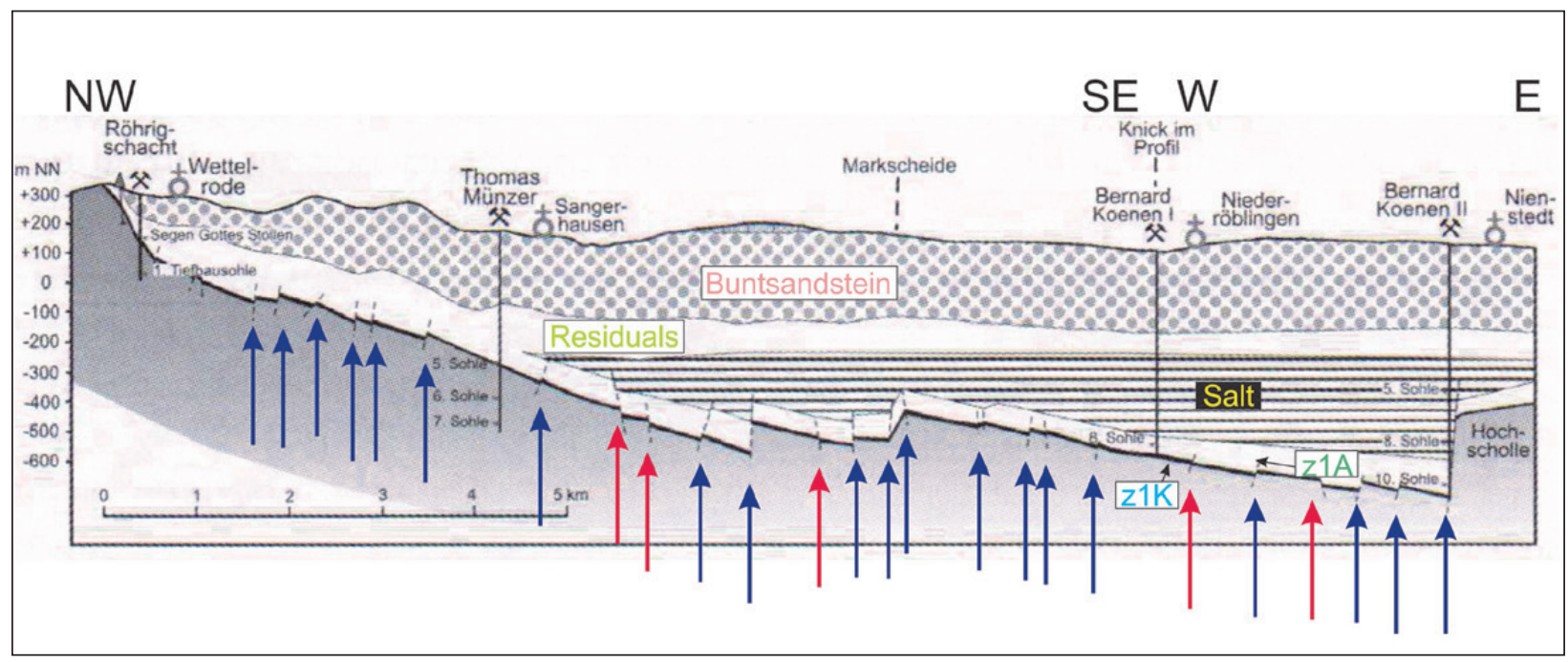

Fig. 4: NW-SE profile (between the mines Röhrig and Bernhard Koenen II) through the Sangerhausen Basin according to results of coppershale mining illustrating faulting (Stedingk et al. 2006). Note the presence of both south-lifting (in part reverse faulting, blue arrows) as well as north-lifting faults (in part normal faulting, red arrows) with the first having the larger sum of thrust. On the right-hand side, the profile bends towards the east (not NE as in the original publication). 


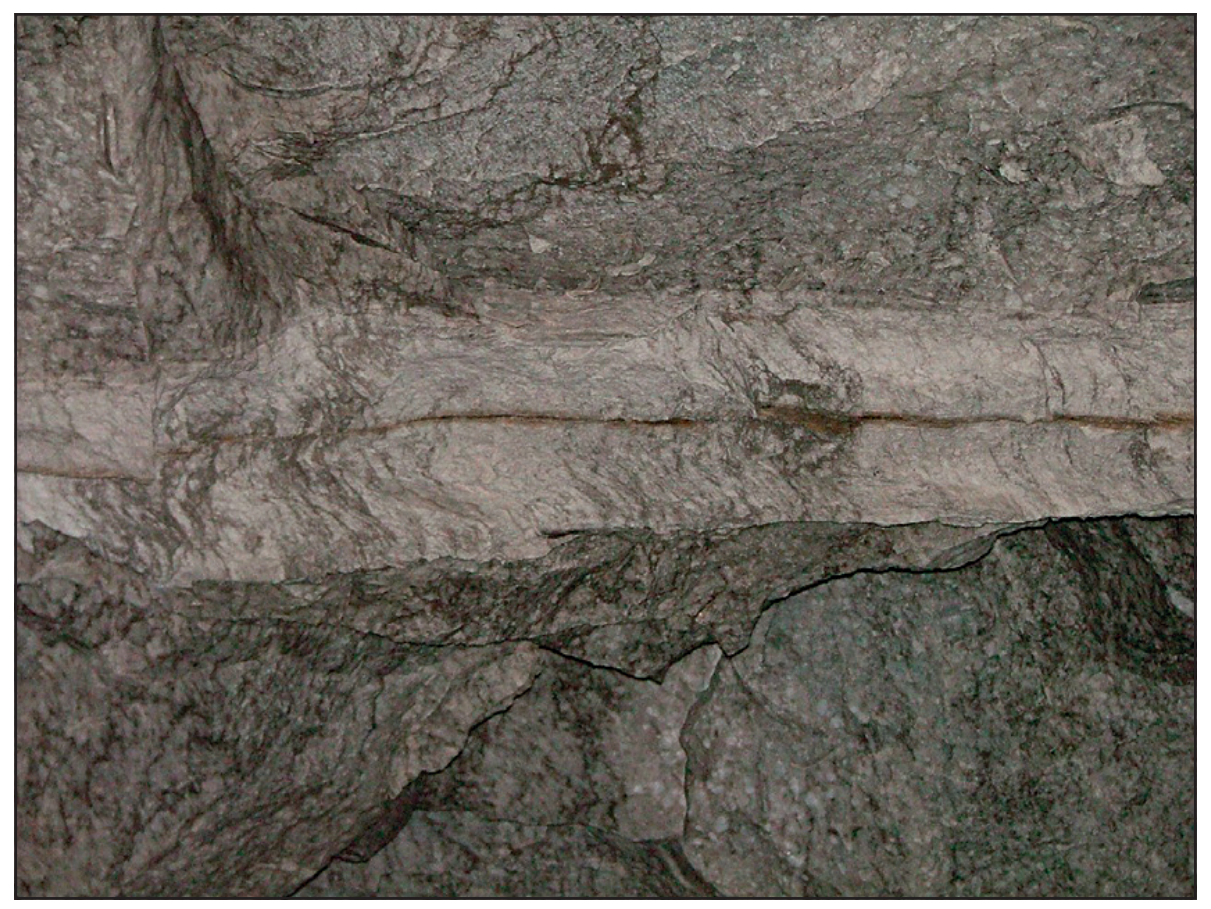

Fig. 5: A tectonic fissure in the ceiling of the Himmelreich Cave, the sides of which have been hydrated to white gypsum within the original gray anhydrite (width of image ca. $1 \mathrm{~m}$ ) (Photo: S. Kempe).

tance between faults, and amount of fault offset all had to be considered. The process was aided by comparing the various overlapping maps in a trial to find the most plausible solution. Thus, faults that were mapped in one section and in the next over could be connected through an intermediate area covered for example by Quaternary. If nothing else was available and away from the Eichsfeld-High, $6^{\circ}$ of dip and thicknesses of $100 \mathrm{~m}$ for the $\mathbf{z 1 A}, 50 \mathrm{~m}$ for the $\mathbf{z 2 A}$ and $50 \mathrm{~m}$ for the $\mathbf{z 3 A}$ was assumed. Including the carbonate and clay strata, a column of 150 to $180 \mathrm{~m}$ (which is similar to the well length of the Zechstein without salt from Quadrant Kelbra, see above) was assumed. This thickness would cause an outcrop width between 1.43 and $1.72 \mathrm{~km}$.

Apart from the high proportion of Quaternary cover, other features make it difficult to locate faults. There are two stratigraphic reasons: (i) Faults within the sulfate formation are almost invisible, because initial fissures in anhydrite that become wide enough to allow passage of seepage water would quickly convert the anhydrite to gypsum that expands and closes the fault fissure. This can, for example, be seen in the ceiling of the Himmelreich Cave (Fig. 5).

The second factor (ii) is the dissolution of gypsum, specifically of the $\mathbf{z} \mathbf{1} \mathbf{A}$. It causes the $\mathbf{z 2 K}$ to collapse over it, draping the z1 A surface with its shards. These can be plowed and used for agriculture so that over thousands of years, slight morphological indications of the fault line were obliterated.
Just as hampering are (iii) the areas covered by residuals. Towards the Harz the $\mathbf{z 1} \mathbf{A}$ is often entirely missing due to dissolution so that the $\mathbf{z 1 K}$ is covered by residuals which in turn are covered by disintegrated $\mathbf{z 2 K}$. The $\mathbf{z 3 A}$ can also be missing, leaving a calcareous, silty and clayey mixture of fine- and coarse-grained fragments.

Faults are located in the field by mapping offsets of the "marker-strata" (z2K and $\mathbf{z 3 T}$ ) ("stratigraphic faults"; labeled " $K$ " in the maps following below). Less certain are locations of faults revealed by rows of sinkholes or linear uvalas ("sinkhole faults"; labeled "E"). In a few instances, caves reveal faults ("cave faults"; labeled "H") like the one exposed in the Große Trogsteinhöhle (Reinboth 1969). Another family of faults are those that arise from constructing the cross-sections ("profile faults"; labeled "S") or that are needed to complete the overall tectonic pattern ("mosaic faults"; labeled "M"). Other faults are placed below obvious valleys and river courses ("valley faults"; labeled F). Finally, faults are revealed by wells because the depth, where certain strata are reached, does not fit with neighboring wells or exposures ("well-derived faults"; labeled "B").

For each of the fault segments, category-label, length and direction are saved in ArcGIS ${ }^{\mathrm{TM}}$ allowing further statistical analyses. In order to discuss specific areas, the entire South Harz was divided into clusters (coinciding with the topographic Quadrants) and partitions (labeled A1 to A18 West to East; Fig. 6). 


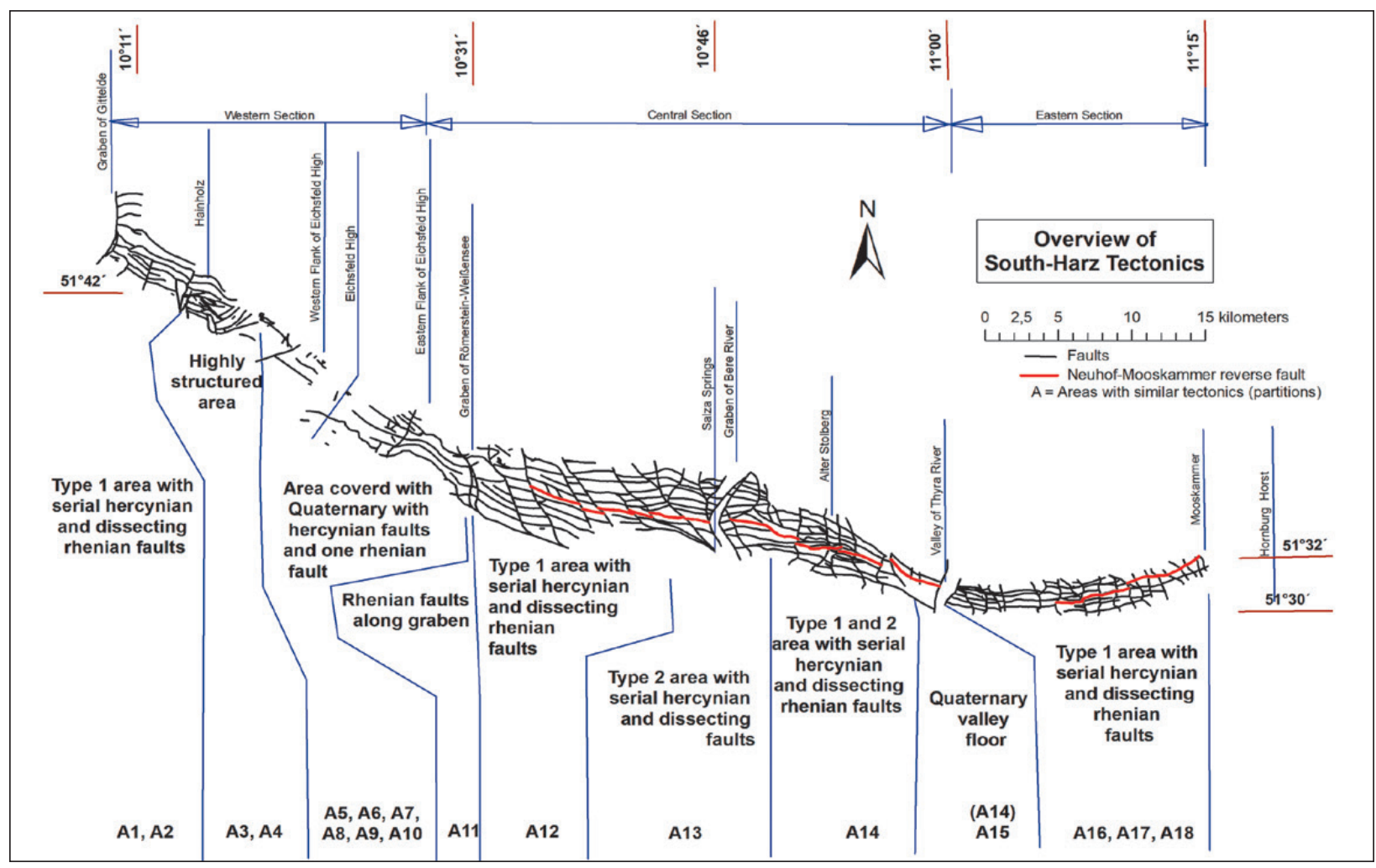

Fig. 6: Overview of the tectonics of the South-Harz Zechstein Belt. The fault drawn in red is the prominent Breitungen-Mooskammer reverse fault.

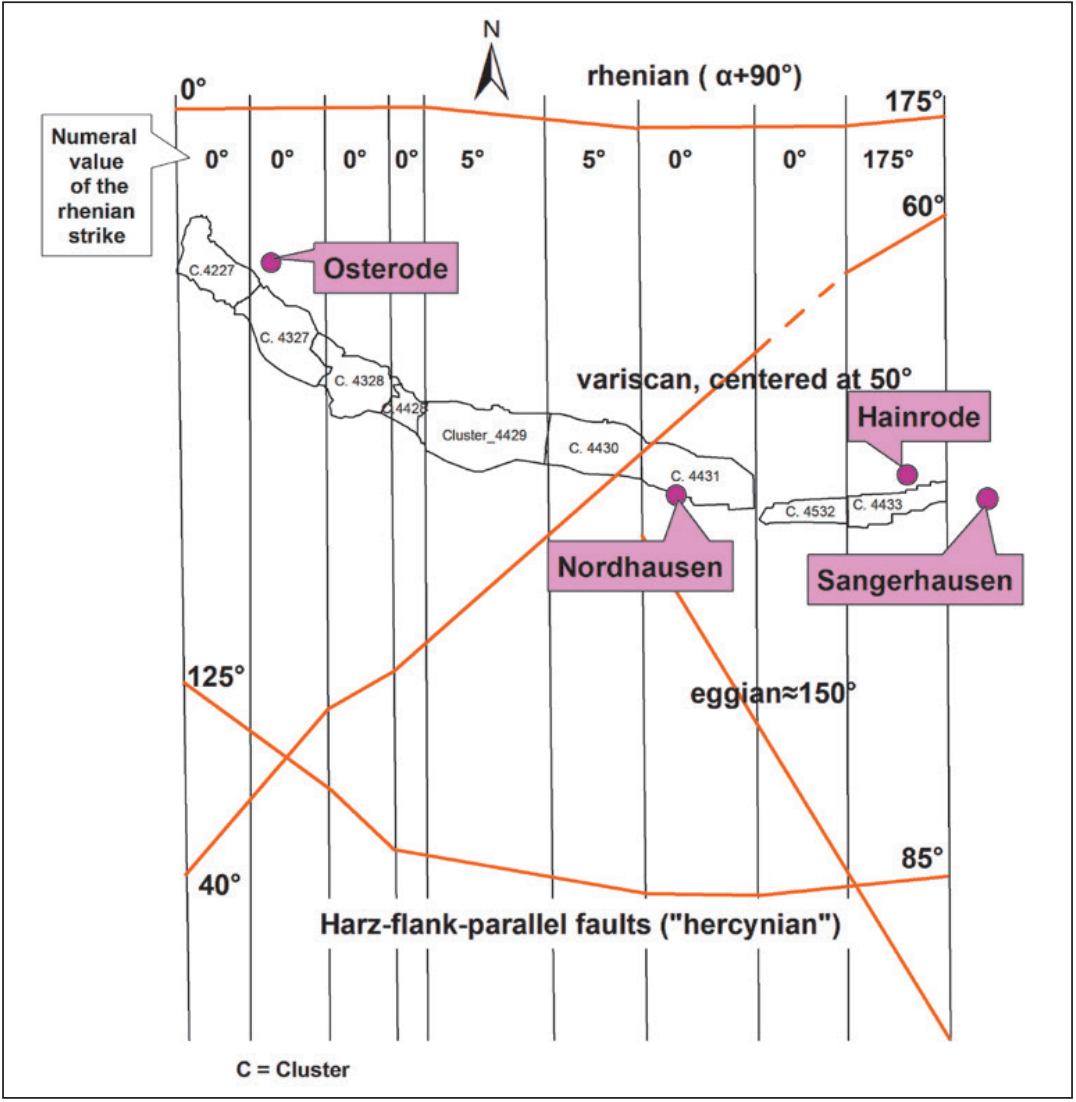

Fig. 7: Illustration of the dominating strike directions, averaged per cluster. (Note that the rhenian direction has to be turned by $90^{\circ}$, correct strike values are given below line). 


\section{TECTONIC MODEL}

Mapping showed that "stratigraphic faults" are relatively closely spaced, i.e. with distances often less than $100 \mathrm{~m}$. It would be wrong to assume that all of them are reverse, south-lifting faults responsible for extending the exposure width of the Zechstein Belt. On both sides of the Questenberg-Valley, which offered excellent exposures along steep valley sides, we find five well-documented reverse faults and one normal fault. Thus, there is a graben that is also revealed by the presence of a hummock of red clays and fine-grained sandstones of the Lower Buntsandstein being preserved among flanking gypsum exposures. This situation, remains of Lower Buntsandstein within the gypsum area, is also found elsewhere, suggesting that grabens are extensive features in the South-Harz tectonics.

Figure 7 summarizes the network of faults derived for the Zechstein Belt giving their average directions per cluster. Its predominant direction follows the fringe of the South Harz and rotates from NW-SE to a more NESW direction. These seem to result from compressional forces and therefore date into the time, when the Harz was uplifted, i.e. into the Upper Cretaceous. One of the compressional reverse faults is the Breitungen-Mooskammer Fault that can be followed from Cluster A12 to A18 (Fig. 6). It is specifically prominent near Hainrode, both morphological as well as by stratigraphic off-set.

However, the Harz-flank-parallel faults are dissected by others, more or less striking perpendicular to these. They re-occur at distances of kilometers in a wider spacing than the former, bracketing blocks longer than wide. In the field these can be seen in many areas, e.g., at Hainrode where N-S trending faults (rhenian) are offstetting the Harz-flank-parallel faults (hercynian), suggesting that they are younger and that they are mostly associated with the N-S graben systems creating the river valleys that cross the Zechstein Belt. Therefore, these tectonic elements can be attributed to the third period of inversion tectonics, i.e. the ongoing dilation of the European Continent in Cenozoic times.

These sensu lato rhenian faults seem to be responsible for the consequent course of Harz rivers where they cross the Buntsandstein escarpment. In the Paleozoic Harz, the south-bound rivers follow the variscan (NE-SW) direction and then are deflected into a Harz-flank-parallel (subsequent) direction when entering the Zechstein Belt. The alternative hypothesis that the valleys are antecedent (their courses predating the uplift, like the Middle-Rhein valley) is not acceptable because then the rivers would not show a deflection to subsequent course. Thus, the consequent section of the valleys of the Söse, Sieber-Oder, Steina, Bere, Thyra, Nasse and Leine seem to be of young age, caused by the tectonic dilatation, allowing them to cross the Lower Buntsandstein escarpment southward, while Uffe, Wieda and Zorge fail to do so. Furthermore, one must take into account that the eastern Harz and the South Harz were covered by the Elsterian Glacier (MIS 12, ca. 450,000 aBP). It reached west at least beyond Nordhausen and must have filled and blocked the rivers from the Bere eastward. Furthermore, the wide-spread presence of the Oberterrasse (upper terrace) shows that once rivers were able to deposit sediments outside of present valleys.

Overall, the derived tectonic model looks like a mosaic. The faults mapped or constructed seem to divide some areas rather regularly. This may look rather artificial, but one must remember that this is a model trying to tie together mapped faults with the hypothesis that the Zechstein-basis continues dipping southward without leveling off (Fig. 4). Otherwise the back-rotation of the Cretaceous uplift of the Harz would result in a northward dip of the Zechstein basis, an unlikely assumption. It also must be remembered that the locations of the constructed faults are only best guesses. However, where running below valleys, they are much better constrained in their position.

\section{REGIONAL TECTONIC MODELS}

Before we can discuss the hydrogeology of the important springs and cave areas of the South Harz in view of tectonics, a more detailed overview of three key areas is given.

\section{THE OSTERODER PLATEAU}

West of Osterode the Zechstein forms a NE-SW striking plateau (Fig. 8). It is bordered in the east at Förste by the Gittelde Graben, and in the south by the Sieber valley.
The Hainholz/Beierstein with the caves Klinkerbrunnen, Martha- and Jettenhöhle, is located in the SW. To the NE, the folded variscan rocks of the Harz rise and in the SW the Zechstein is covered by the Lower Buntsandstein forming an escarpment. Fig. 9 gives the constructed profile through the plateau (magenta line in Fig. 8), illustrating the function of south rising faults to extend the width of the plateau. The $\mathbf{z 1} \mathbf{A}$ is largely covered by the disintegrated and collapsed $\mathbf{z 2 K}$ hiding most of the 


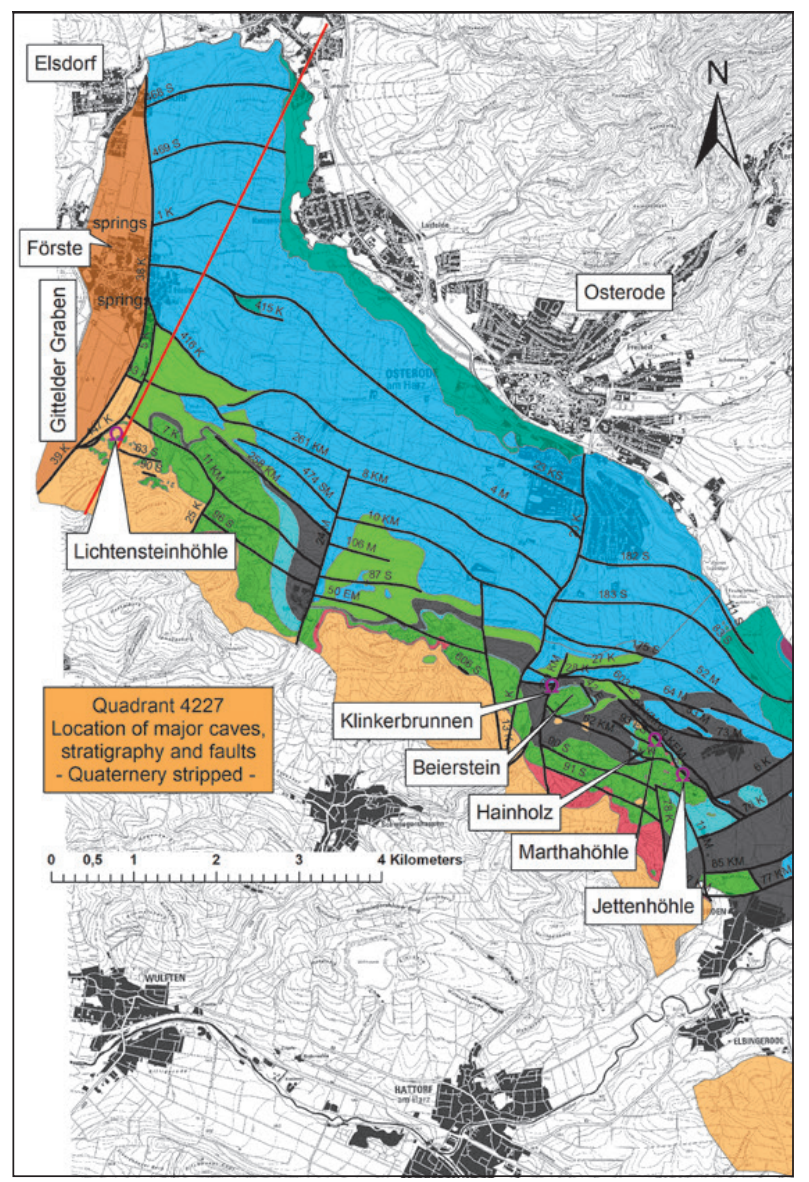

Fig. 8: Geology - stripped of the Quaternary cover - and derived tectonics of the Osteroder Plateau (the western section of the Zechstein Belt). The line of the profile in Fig. 9 is marked in magenta. Colors refer to Tab. 1. Faults are labeled to identify them in ARCGIS. Letters refer to how the fault was identified as explained in the previous chapter.

faults. The $\mathbf{z 1 A}$ is only exposed along the NE where it forms an impressive escarpment, today largely destroyed by quarrying for gypsum. Further south the upper Zechstein series are partly situated in grabens. The $\mathbf{z 3 T}$ covers larger areas towards the $\mathrm{S}$. The $\mathbf{z 2 A}$ diminishes in thickness SE-wards towards the Eichsfeld High, which is also true for the $\mathbf{z} \mathbf{3}$.

\section{RÖMERSTEIN - WEISSENSEE GRABEN}

The Römerstein-Weißensee Graben is a hydrologically and geomorphologically closed N-S striking valley (Priesnitz 1969b). On the published geological Quadrant 4429 two very short, N-S striking faults are marked that border an only $500 \mathrm{~m}$-wide tectonic graben (Fig. 10 a,b). This was already described by Haase (1936). Its western flank is marked by the Römerstein, a prominent z1K-D exhumed stromatolite reef, and the eastern rim is formed by the Tettenborn $\mathbf{z 2 K}$ plateau. According to the results of a well drilled at the Römerstein (Paul 1987), the western fault (Römerstein-Fault) must have a displacement of at least $100 \mathrm{~m}$, while the eastern fault (the Weißensee-Fault) has a somewhat smaller displacement. To the north the faults may converge into one fault along which the river Steina cut its course. The Graben most likely terminates south at the hercynian-striking Ichte-Fault. This fault continues as Helmetal-Fault (compare Fig. 1) forming a prominent valley within the Lower Buntsandstein west of Nordhausen. This fault may have acted as a strikeslip fault, re-activated to compensate the expansion of the Graben. It is filled by Harz-derived gravel and sediments of the Quaternary Lower Terrace forming a plain interrupted by active sinkholes including the Weißensee sinkhole. These sinkholes reveal the presence of the z1A within the graben. The terrace is the product of the river Steina that, at high water, runs today west of the Graben. It sinks for most of the year entirely when reaching the Zechstein. A prominent S-lifting fault is exposed in the Große Trogstein Cave (Reinboth 1969) where the Zehntgärtenbach sinks (right).

\section{THE ZECHSTEIN NORTH OF NORDHAUSEN TO BOTH SIDES OF THE BERE VALLEY}

The Zechstein area north of Nordhausen (Fig. 11 top) is dissected by a curved graben (Fig. 11 bottom) used by the Bere river to break through the Lower Buntsandstein escarpment. The $\mathbf{z 1} \mathbf{A}$ is the most prominent formation of the area. It is draped by the disintegrated $\mathbf{z} 2 \mathrm{~K}$. Several south-lifting, E-W striking faults are responsible for the repeated uplift of the south-dipping z1A. Two grabens and one horst, striking E-W, are present (Fig. 11 bot-

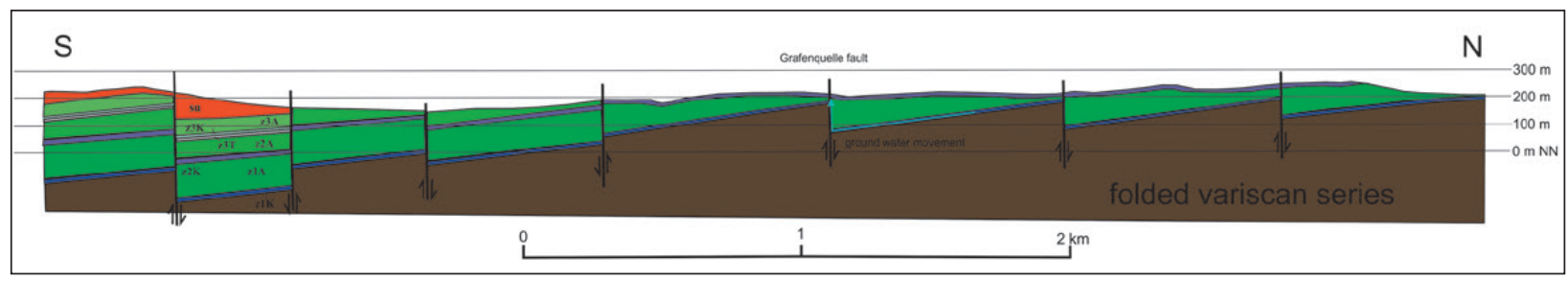

Fig. 9: Westernmost geological profile (location see Fig. 8) of the Zechstein plateau east of Förste, showing the repeated system of south rising faults. The longest fault - 23KS (see Fig. 8) - is probably the one responsible for gypsum-loaded mineral water supplying the "Grafenquelle", one of the Salza Spring-complex. 


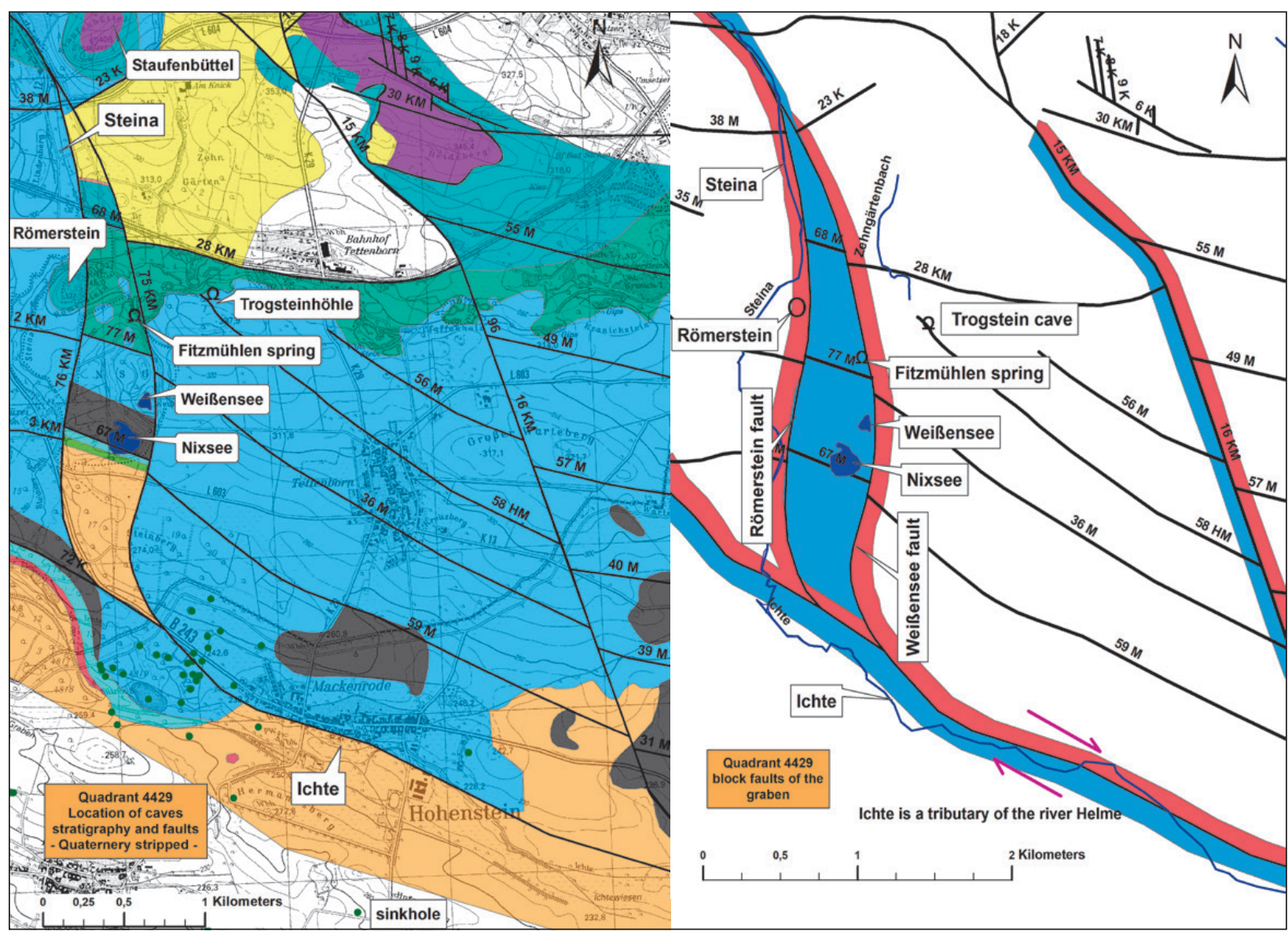

Fig. 10: Geological (left) map, stripped of Quaternary, and tectonic model (right) of the Römerstein - Weißensee Graben. Blue color denotes the graben. Colors along faults mark relative thrust: red is up, blue down.

tom). The horst coincides with the Himmelberg/Bromberg/Mühlberg ridge. The southern of the grabens is filled with lower Buntsandstein and upper Zechstein, it can be traced across the Bere Valley (Fig. 11 bottom). It is used by the Sachsengraben and Zorge river, tributary to the Bere.

The upper Zechstein sulfates $(\mathbf{z 2 A}, \mathbf{z 3 A})$ are not prominent on the western flank of the Bere Graben, gaining thickness only on its eastern side. Later, NW-SE striking faults structured the area further. Those on the western side of the Bere Graben seem to converge to an important karst spring, the Salza Spring.

In the published geological map (Quadrant 4430, Nordhausen-Nord; Schriel \& v. Gaertner 1930) a hypothetical profile of the region was published (Fig. 13). It shows a strange, folded uplift, disturbed by several hercynian faults. One of the faults does not continue into the Zechstein but affects only the Rotliegend and the basement. Therefore, it must be dated into the narrow time span at the turn of the Rotliegend to the Zechstein, a highly unlikely event. Furthermore, the thickness and stratigraphic differentiation are different on both sides of the fault. This can only be explained, if the authors assumed that this is a transform fault. There is no real evidence for the fold and its faults in the field, nor do the authors explain why they have constructed it. Our guess is that they were puzzled by the large width of the $\mathbf{z 1 A}$ exposure, which, in our model, is explained by a series of south-lifting faults. The Zorge Graben is explained as a syncline in the historic profile.

\section{THE REVERSE FAULT AT HAINRODE}

One of the best exhumed fault lines of the South Harz extents east of the small village of Hainrode, NW of Groß Leinungen, towards the end of our investigation area (Fig. 14). Here the S-sloping z1K (Zechsteinkalk) is partly stripped bare of the overlying strata and exposed at several places. It forms a ridge that exposes the underlying Upper Carboniferous sediments (Mansfeld Formation, Stefanian) at its crest. North of the ridge, the Zechstein is reoccurring in a valley starting with the disintegrated $\mathbf{z 2 K}$ (Stinkschiefer), followed uphill by the residual (cavernous carbonates and marl) z1 A and again by the $\mathbf{z 1 K}$. Lines of pits mark the former 
outcrop of the underlying z1T (Kupferschiefer, coppershale) that has been mined since Bronze Age. The $\mathbf{z} 1 \mathrm{~K}$ is dotted by piles of waste where the later miners dug pits to extract the copper-shale from underneath the Zechsteinkalk. N-S striking faults offset the Hainroder fault at distances of several hundred meters. The Hainroder
Fault has a thrust of at least $50 \mathrm{~m}$, leading to a broadening of the Zechstein outcrop width. To the east, below the Ohmischen Berg and in the area of the Mooskammer, the fault runs in a valley within the upper Carboniferous. Such a valley could only have been formed because it was incised by dissolving the Zechstein sedi-

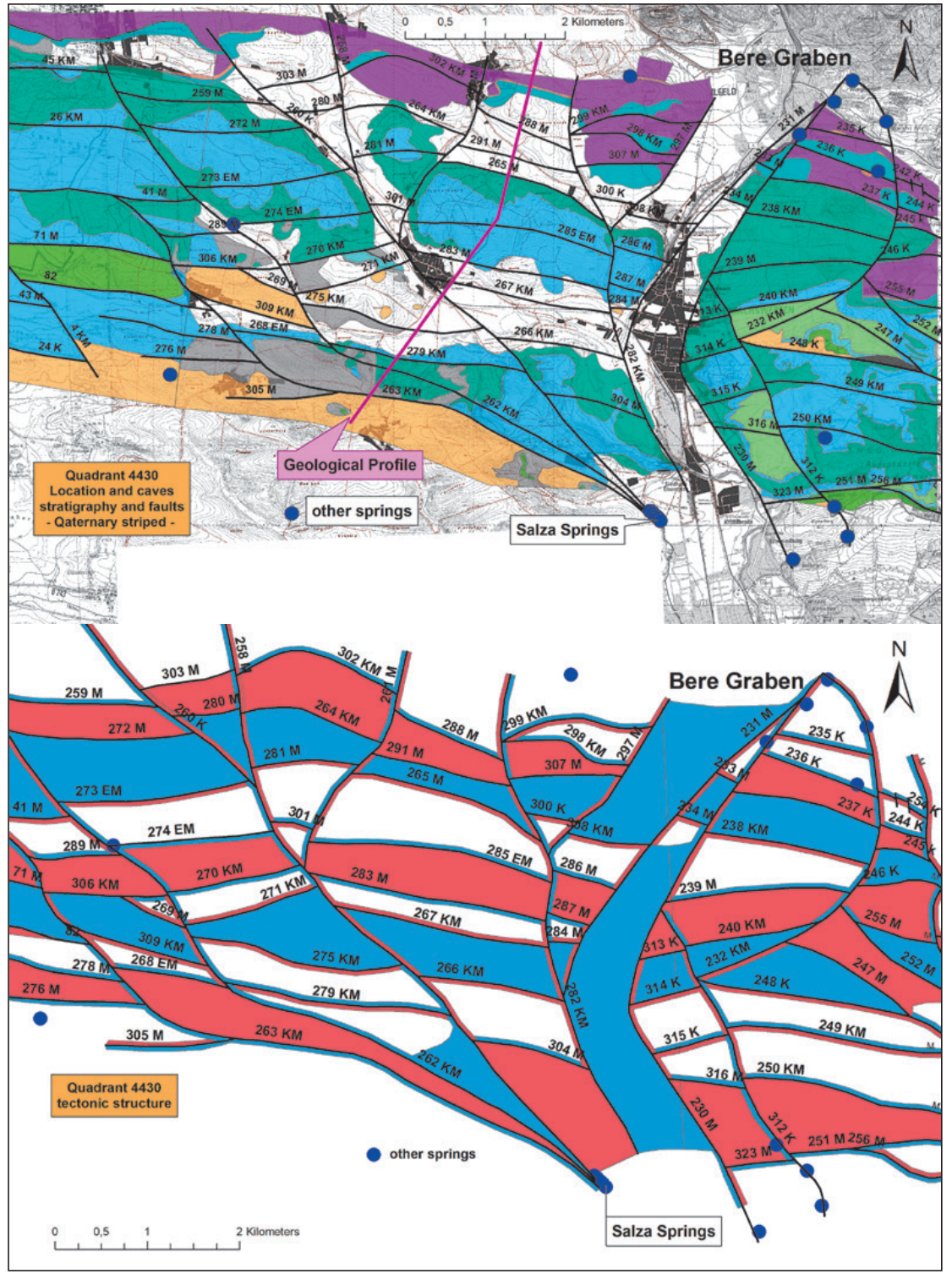

Fig. 11: Geological (top) and tectonic map (bottom) of the Zechstein Belt on both sides of the Bere Valley north of Nordhausen. Top: White areas are covered by thick Quaternary deposits. Line of profile (Fig. 12) is marked in magenta. Bottom: Map showing the tectonic structure. Red color denotes horst, blue color graben. Areas marked in white are Sdipping blocks in-between. Colors along faults mark relative thrust: red is up, blue down.

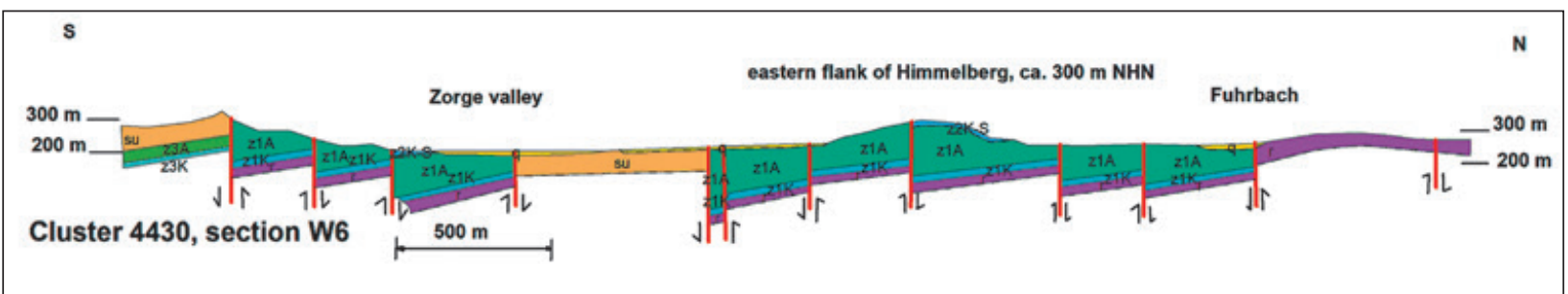

Fig. 12: Geological profile through the Zechstein plateau west of the Bere Graben. Note the repeated uplift of the z1A due to a series of southlifting faults. Note Zorge valley graben occupied by Lower Buntsandstein. For location see Fig. 11. 
ments along the face of the impermeable reverse fault (Fig. 15). After removing the gypsum and limestone, the water course got stuck at the position of the fault, deepening the valley into impermeable rock by erosion. The river running through the valley westward sinks at the contact with the $\mathbf{z} 1 \mathrm{~K}$ and causes ongoing subrosion in the z1A below Groß Leinungen, making it the most sinkhole-prone village in the region.

To the west of Hainrode the reverse fault is offset by a few hundred meters to the south but can be followed from there for many kilometers west until Breitungen (red line in Figs. 6 and 14).

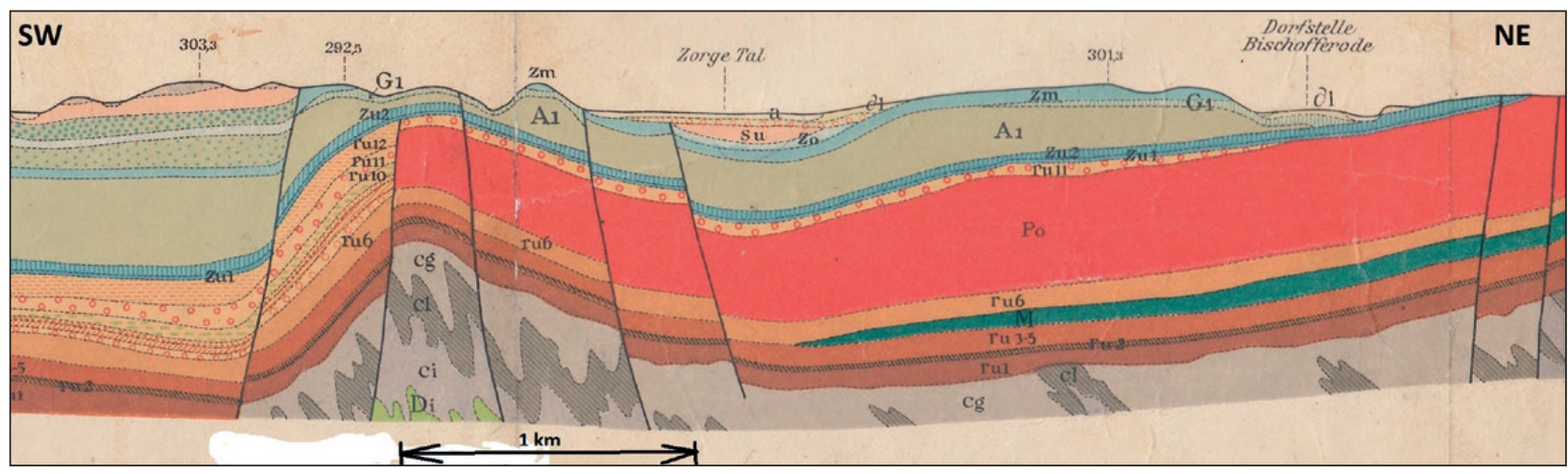

Fig. 13: Historic geological profile of Quadrant 4430, Nordhausen-Nord (Schriel \& v. Gaertner 1930). Abbreviations different from those used here: Zo: Upper Zechstein (z2A and z3A); Zm: Middle Zechstein (z2k); A1: z1A; Zu1, Zu2: Lower Zechstein z1t, z1k; G: Gypsum; P: Lower Permian porphyrites; $r$ : various lower Permian sediments; M: melaphyrs. For location see Fig. 11.

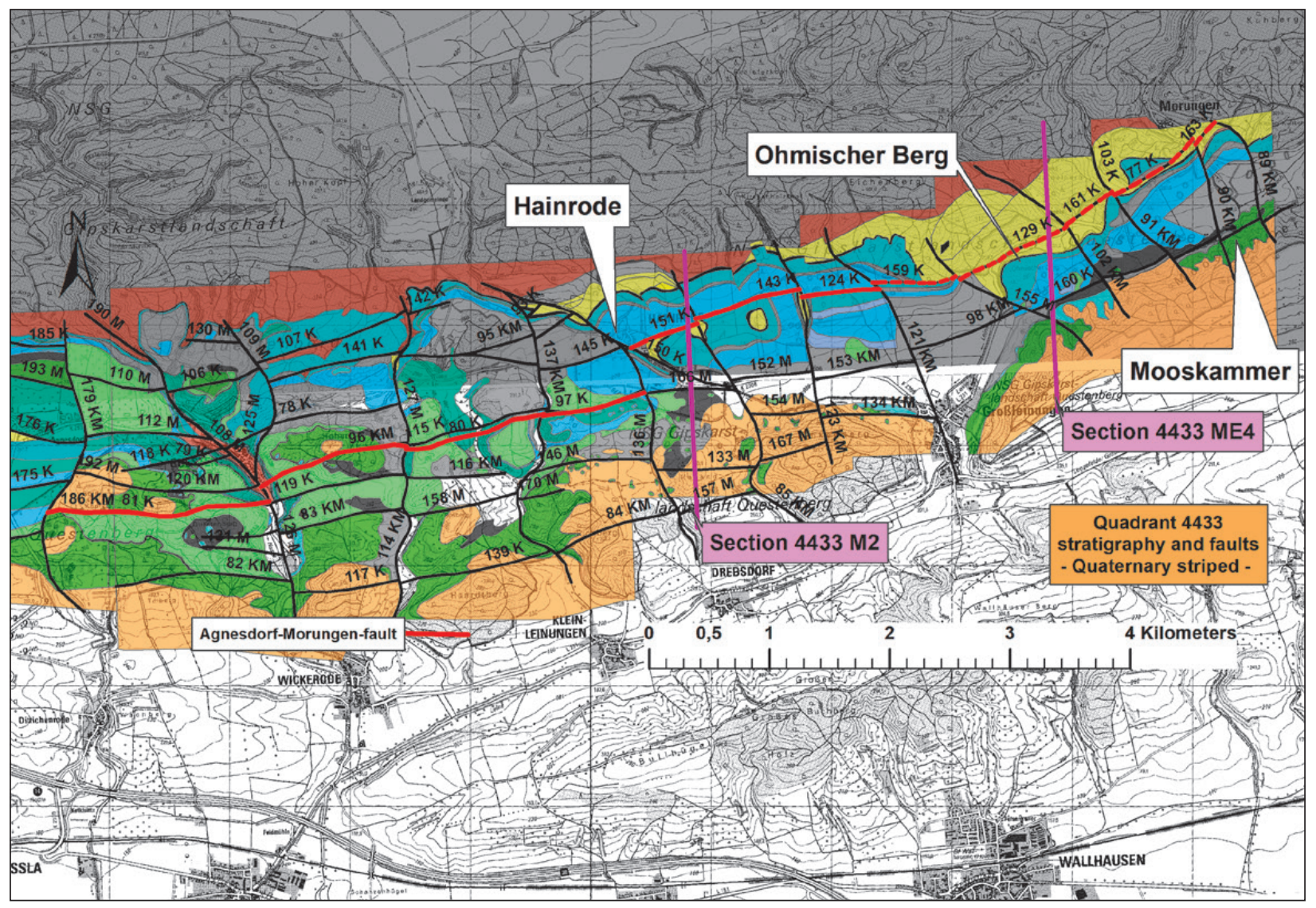

Fig. 14: Geological map and tectonic structure of the South Harz Zechstein around Hainrode, stripped of Quaternary deposits. The Breitungen-Mooskammer reverse Fault is marked in red; Profile lines of Fig. 15 are marked in magenta. 


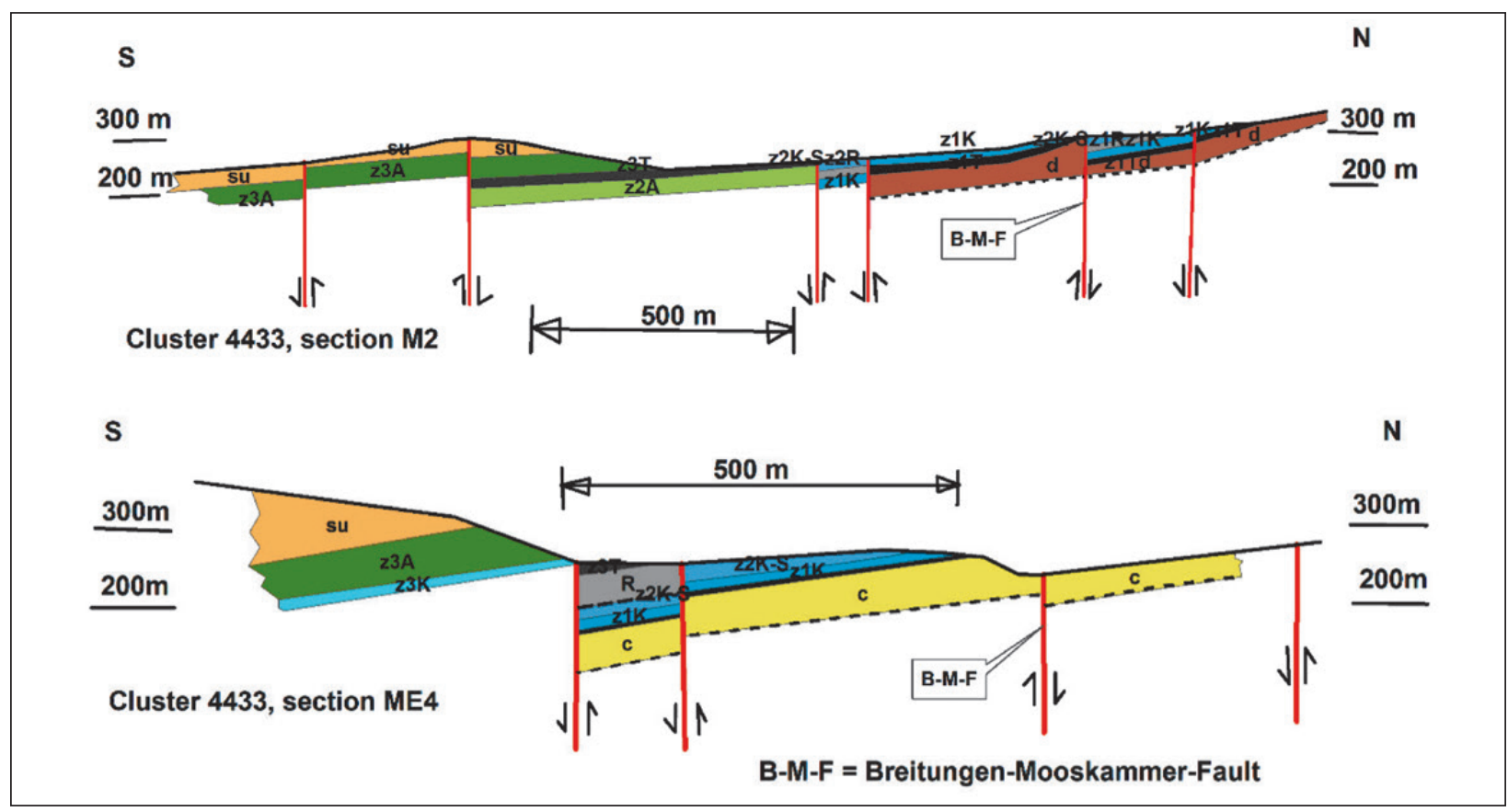

Fig. 15: Two profiles through the Breitenfelde-Mooskammer reverse fault at Hainrode (top) and Omischen Berg (bottom). Profile lines are marked in Fig. 14. B-M-F = Breitungen-Moosskammer-Fault.

\section{DISCUSSION OF KARST HYDROGEOLOGY OF THE SOUTH HARZ ZECHSTEIN BELT IN VIEW OF THE REGIONAL TECTONICS}

One of the outstanding features of the Zechstein Belt is that most of the rivers crossing it, sink when arriving at the $\mathbf{z 1 K}$ or $\mathbf{z 1 A}$. Of the rivers Söse, Sieber, Oder, Steina, Uffe, Wieda, Zorge, Bere, Thyra, Nasse and Leine only the Söse has appreciable summer discharge, all others can dry out entirely. It is not exactly known for some of these, where their water reappears.

\section{THE SALZA SPRING AT FÖRSTE}

The tectonic model derived has unexpected consequences for our understanding of the South Harz karst landscape and its hydrogeology. One of the three large karst springs (Fig. 1) is the Salza-Spring at Förste (Haase 1962), at the western-most end of the South Harz. Fig. 8 gives the stratigraphy and tectonics of the area of cluster 4227. The Salza-Spring seems to be located at the western end of one of the reverse faults structuring the plateau (Fault $23 \mathrm{KS}$ ). This fault, as several of the others, is lifting the southern strip-like block up so that below the groundwater is prohibited to flow south within the $\mathbf{z 1 K}$ (Zechsteinkalk) below the Werra Anhydrite. Fault $23 \mathrm{KS}$ would therefore divert water along an extensive front, including all the water that may sink within the Söse valley and its gravel body of the lower terrace. The other faults would not have such a long front so that they, despite running in parallel, do not have such a capacity to divert water underground.

The Grafenquelle, the eastern-most of the SalzaSpring complex of 35 springs (Fig. 16), was formerly used commercially for mineral water. It has a high sulfate and a low chloride concentration marking it as having derived from gypsum karst. Many of the other springs contain several grams of salt, as the name of the spring suggests. The halite could not have originated from the gypsum karst of the Osteroder Plateau but must be derived from the Gittelde Graben to the west. The Graben is filled with Buntsandstein (Hintze \& Jordan 1981) and the Zechstein below still contains salt. Halite bearing solutions are probably rising along the eastern boundary fault of the Gittelde Graben and mix with the water from Fault 23KS.

Historically, the salt-rich springs seem to have been the source of a certain wealth of the local Bronze Age population that used the Lichtensteinhöhle (Kempe \& Vladi 1988, 2019) for secondary burials and memorial rites. The cave became world-renown because the recovered bones allowed the reconstruction of family lines by DNA for the first time for ancient societies (Flindt 2004). Being a very narrow epigenic cave, its gallery is determined by the local tectonic joints, i.e. pre- 


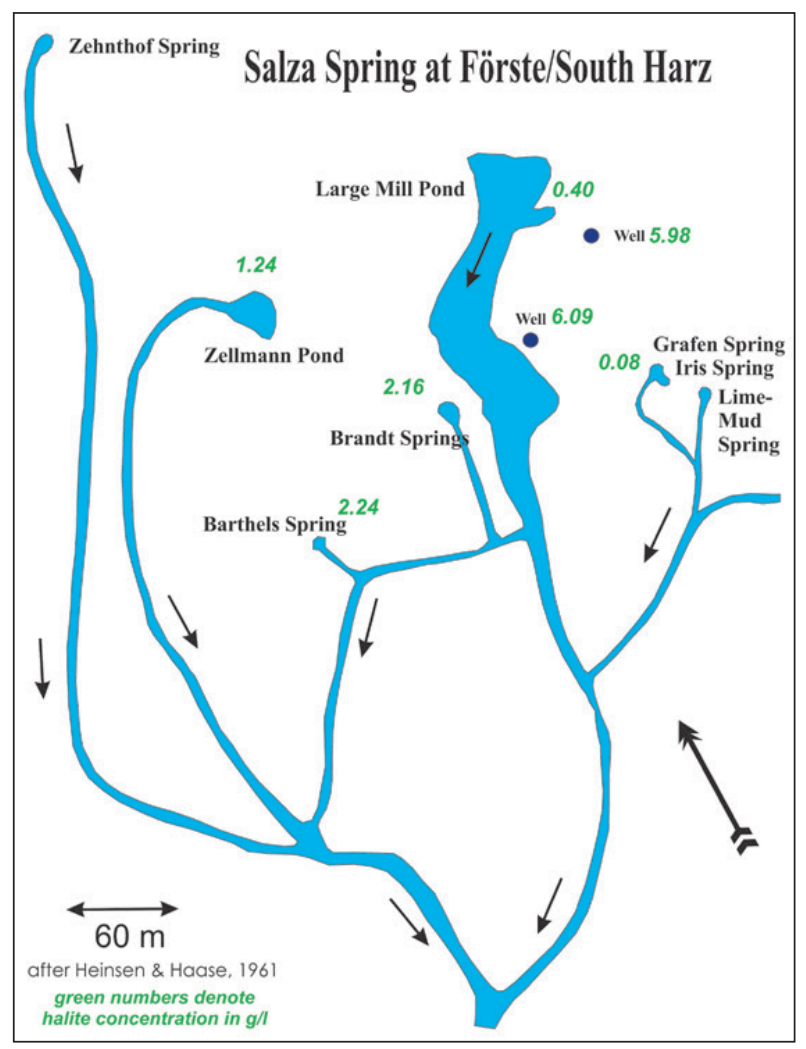

Fig. 16: Sketch of the Salza-Springs at Förste with halite concentrations in g/l (redrawn after Heinsen \& Haase 1961, q.v. Kempe \& Vladi 2019).

dominantly variscan $\left(40-50^{\circ} \mathrm{N}\right)$ and hercynian $\left(130^{\circ} \mathrm{N}\right)$ (compare also the western cluster of Fig. 7) (Kempe \& Vladi 1988).

\section{THE HAINHOLZ-BEIERSTEIN PRESERVE}

The Hainholz-Beierstein, a 600 ha-large Natural Preserve features several larger gypsum caves, i.e. Klinkerbrunnen, Marthahöhle and Jettenhöhle (Fig. 8). More than 20 other caves, mostly small, are known in the area (Kempe et al. 1972). Tectonically, the area is characterized by faults that include a $\mathbf{z 3 A}$ (Hauptanhydrite) graben (Kempe et al. 1970). Thus, small creeks collecting on the $\mathbf{z 3 T}$ are sinking at contact with the gypsum while on the other side of the graben, karst springs, saturated in gypsum, are issued (Brandt et al. 1976; Kempe 1982). The Jettenhöhle, in total $750 \mathrm{~m}$ long and featuring a series of large halls, is formed by calcite-saturated water ascending from the z2K-D (Stinkdolomit), a shallow hypogenic setting (Kempe 2014). In order for the water to rise, it has to cross the $\mathbf{z 3 T}$ (Grauer Salzton) that is intercalated between Hauptanhydrit and Stinkdolomit. This can only be done along faults (Kempe 2019). Thus, the existence of the Jettenhöhle reveals the presence of many more faults than are mappable on the surface. Mignat (1984) studied the jointing of the karren fields of the Hainholz as well as joints and filled fissures in the Marthahöhle and joints and general directions in the Jettenhöhle. His detailed analysis of hundreds of measurements and lineations showed the predominance of hercynian-rhenian jointing systems with noticeable eggian-variscan components. These observations are in accordance with the results of this study (compare Fig. 4).

\section{THE RHUME SPRING}

The largest South-Harz karst spring and one of the largest in Germany, is the Rhume Spring (Fig. 1), source of the Rhume River. The spring rises from a 9 to $10 \mathrm{~m}$ deep pot without any larger cave opening at the bottom (Frickenstein \& Wunsch 1966). It discharges around $2 \mathrm{~m}^{3} / \mathrm{s}$ on average with a minimum of 0.96 and a maximum of 5.43 $\mathrm{m}^{3} / \mathrm{s}$ (Haase 1936; Liersch 1988). Its geological situation is also bound to tectonics: the spring rises out of the Zechstein z2K-D, while southwest of it the Lower Buntsandstein (su2) is down-faulted by $120 \mathrm{~m}$ (Herrmann 1969b). NE of the spring the su2 is also present, but more in the form of collapsed material overlaying the Zechstein. Hermann notes that sinkholes occur to the east but not to the west of the Rhume Spring. Thus, it appears as if the fault prevents any water to move further SW than the spring while salt and gypsum is dissolved to the NE of the fault. Missing layers (between the z2K-D and the su2) at the northern side complicate this interpretation. The tributary area of the spring is estimated by Herrmann to $350 \mathrm{~km}^{2}$. It includes the areas of the rivers Sieber and Oder in the Harz that sink 6 to $9 \mathrm{~km}$ to the northeast of the spring. In summer, these rivers can sink entirely. Uranine tracing has shown that their water reappears at the spring (q.v., Böttcher \& Rienäcker 1990). Haase (1958) calculated from 10-year discharge measurements that the rivers provide $62 \mathrm{mio} \mathrm{m}^{3} / \mathrm{a}$ of water to the spring annually, while 19 mio $\mathrm{m}^{3} / \mathrm{a}$ are provided by precipitation sinking in between sinks and spring in the heavily karstified Pöhlder Basin NE of the spring. This brings the total discharge of the spring to $81 \mathrm{mio} \mathrm{m}^{3} / \mathrm{a}$. The Pöhler Basin is covered with thick terrace sediments thus placing it outside of the remapping of the current study of the Zechstein Belt. Due to the importance of the Pöhlder Ba$\sin$ as a groundwater reservoir it was explored by several wells, summarized by Jordan (1979) and Liersch (1988). The constructed profiles show several reverse faults as well as graben structures. However, the general dip to the south is not taken into account in these profiles and the frequency and direction of faults is difficult to reconstruct from exploratory and productive wells alone. In view of the $3 \mathrm{~km}$ wide basin, the total thrust of reverse faults should be larger than the sum of thrusts along normal faults. 


\section{THE RÖMERSTEIN-WEISSENSEE GRABEN}

The Zehngärtenbach and its small tributaries, that sink in the Kleine and $435 \mathrm{~m}$ long Große Trogsteinhöhle (Reinboth 1969) (Fig. 10), flows along a reverse fault (4429$58 \mathrm{HM}$ ) that uplifted the underlying $\mathbf{z 1 K}$-D forcing the collected water to flow along the eggian striking fault southeastward for $165 \mathrm{~m}$. The surface of the dolomite dips towards the southwest until it is at the level of the Fitzmühlen Spring, so that the vadose creek can turn west towards the spring flowing on top of the dolomite. Exploration of the Fitzmühlen Spring Cave (map by Andreas Hartwig, pers. com., 2007) yielded $545 \mathrm{~m}$ long, very low passages that zigzag along prominent eggian as well as variscan and hercynian joints without getting near the Trogsteinhöhle (Stolberg 1926; Biese 1931; Reinboth 1969; lengths by Kempe \& Helbing 2000). The connection between the two caves is extremely low and remains unexplored.

The Fitzmühlen Spring Cave and water re-appearing from the Steina deliver water to a creek that has cut 6 $\mathrm{m}$ deep through the Steina terrace discharging its water south to an 8 ha-large, wide flat including the periodic Nixsee, interpreted as a karst polje (Priesnitz 1969b). The flat is devoid of sinkholes and can hold water for months, indicating that the underground is composed of the impermeable z3T (Grauer Salzton). The water of the Nixsee sinks in a ponor at its eastern border in the $\mathbf{z 3 A}$, with unknown re-occurrence.

\section{THE SALZA SPRING AT NORDHAUSEN}

Another important gypsum karst spring, also called "Salza Spring", is located north of the city of Nordhausen (Figs. 1, 11), albeit outside of the Bere valley and below the $\mathbf{z 1 A}$ ridge of the Kohnstein, once the site of the concentration camp Dora. It was infamous for its cruelty and the building of the V1- and V2-weapons in artificial tunnels within the $\mathbf{z} \mathbf{1} \mathbf{A}$ anhydrite.

The discharge of the Salza Spring is about $0.4 \mathrm{~m}^{3} / \mathrm{s}$ on average with a maximum of 1.4 and a minimum of $0.15 \mathrm{~m}^{3} / \mathrm{s}$ (q.v. Völker \& Völker 2016). The name of the spring and its river suggests that the spring carries salt. Already Behrens in 1703 pointed this out, but apparently failed to taste any. Not many water analyses were published; Haase (1936) made 13 chloride-analyses from samples taken between the $6^{\text {th }}$ of January and the $28^{\text {th }}$ of September 1933, at three of the spring points (Fig. 17) at varying discharges. The averages for the Salza Spring Pond, the Stiefel Spring and the Grundloses Loch Spring were $15.73 \pm 2.05,24.57 \pm 1.83$ and $25.37 \pm 1.91 \mathrm{mg} \mathrm{Cl} / \mathrm{l}$, respectively, representing 26,40 and $43 \mathrm{mg} \mathrm{NaCl} / \mathrm{l}$ (Fig. 17). The standard deviations are similar between the three sampling sites but if recalculated for the coefficient of variation (13.05, 7.44 and 7.53 percent, respectively) it is found that the shallow Spring Pond (the largest source of water) has a higher variability in its $\mathrm{Cl}$-concentration than the other two springs. Haase also pointed out that these latter springs have a slightly higher temperature and a higher total dissolved solid load (analyzed as residual: 1248,1474 and $1663 \mathrm{mg} / \mathrm{l}$, respectively) and argued that these springs derive from deeper conduits with longer residence times. The halite content measured by Haase is much smaller than that of the Salza Spring at Förste. A later analysis by Schuster (q.v. Völker \& Völker 2016) measured a chloride concentration of $240 \mathrm{mg} / \mathrm{l}$ (February $24^{\text {th }}, 1971$ ), which would be clearly a concentration beyond the geogenic background of groundwater unaffected by salt in Germany. Two further analyses yielded only 31 and $71 \mathrm{mg} / \mathrm{l}$ (1981 and May 2016, resp.; Völker \& Völker 2016). Compared to the 13 samples from 1933 these concentrations are higher and represent a higher variability.

Any tectonic model must therefore take into ac-

\section{Salza Spring at Nordhausen/South Harz}

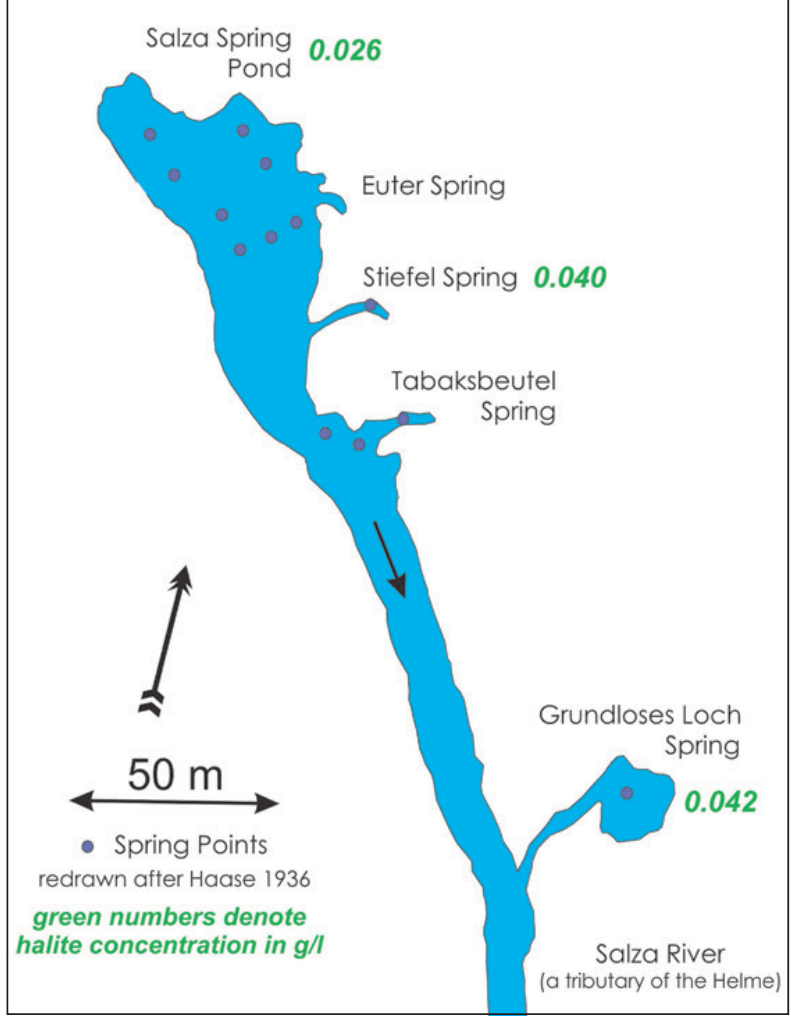

Fig. 17: The Salza Spring at Nordhausen and the halite concentrations in $\mathrm{mg} / \mathrm{l}$ measured by Haase (1936). 
count that the karst water may have had contact to salt layers along its path in the past and occasionally at present. So far, no valid explanation was given for the specific geological situation of the Salza Spring even though Haase (1936) assumed that its waters derive from the Zorge and Wieda rivers sinking to the North.

The old, published profile through the Kohnstein (Fig. 13) that assumed an anticline of impermeable Lower Permian volcanics and/or sediments below the Kohnstein would prevent any karst water flow from the north. Karst water flowing through the $\mathbf{z 1 K}$ and $\mathbf{z 2 K}$ could not reach the Salza Spring and would be diverted along the faults $\mathrm{E}$ to the Bere valley. Our interpretation of the geological map under the assumption of a steady dip towards the south (Fig. 12) explains the reoccurrence of the z1A by reverse faulting. In the E-W striking Sachsengraben/ Zorge valley, separating the two main z1A ridges (Himmelberg/Bromberg/Mühlberg and Kohnstein) Buntsandstein occurs, indicating a tectonic graben. Within this graben, salt may still be present at depth. Also (q.v. Völker \& Völker 2016) salt lenses were found within the z1A during the mining for the artificial tunnels in WWII. These layers could be the source of small amounts of halite.

Our model (Fig. 12) has principally the same problem as the published profile, water would be diverted along the impervious Rotliegend sediments and volcanics along the E-W faults towards the Bere valley. At the surface, these Harz rim parallel faults are responsible for the E-W valley of the Sachsengraben/Zorge. The Fig.12 N-S profile, however, depicts only the E-W striking faults, not those trending perpendicular to them. Fig. 11 shows the geological and tectonic map of the respective area. Several small rivers cut the $\mathbf{z 1 A}$ ridges. They seem to follow faults converging towards the Salza Spring. Along those water can cross the underground barriers created by the reverse faults diverting karst water south until the normal fault (Fig. 12 left) - south of the Salza Spring - forces the water up. This is like the tectonic situation at the Rhume Spring. Along the course of these cross-cutting faults the water could have leached salt remaining in the Buntsandstein Graben or out of the z1A. South of the Salza Spring the downfaulted Buntsandstein protects the Zechstein from leaching. There, salt is still available below ground, as evidenced by sinkholes in the Lower Buntsandstein (Quadrant 4430). It is, however, unlikely that this salt rises from the Salza Spring because it is not hydrothermal but has temperatures like the regional annual mean (see temperature measurements in Haase 1936 and Völker \& Völker 2016). Thus, both the peculiar location of the Salza Spring and its old name find an explanation in our suggested tectonic and geological structure.

\section{THE REVERSE FAULT AT HAINRODE AND ITS HYDROGEOLOGICAL CONSEQUENCES}

Along this Breitungen-Mooskammer Fault at Hainrode (Fig. 14) karstic groundwater is diverted E-W, causing massive dissolution of the lower Zechstein $(\mathbf{z 1 A}, \mathbf{z 1} \mathbf{K})$ illustrated by rows of sinkholes and dry valleys. Karst water can only escape south at substantial N-S faults and grabens (Fig. 18).

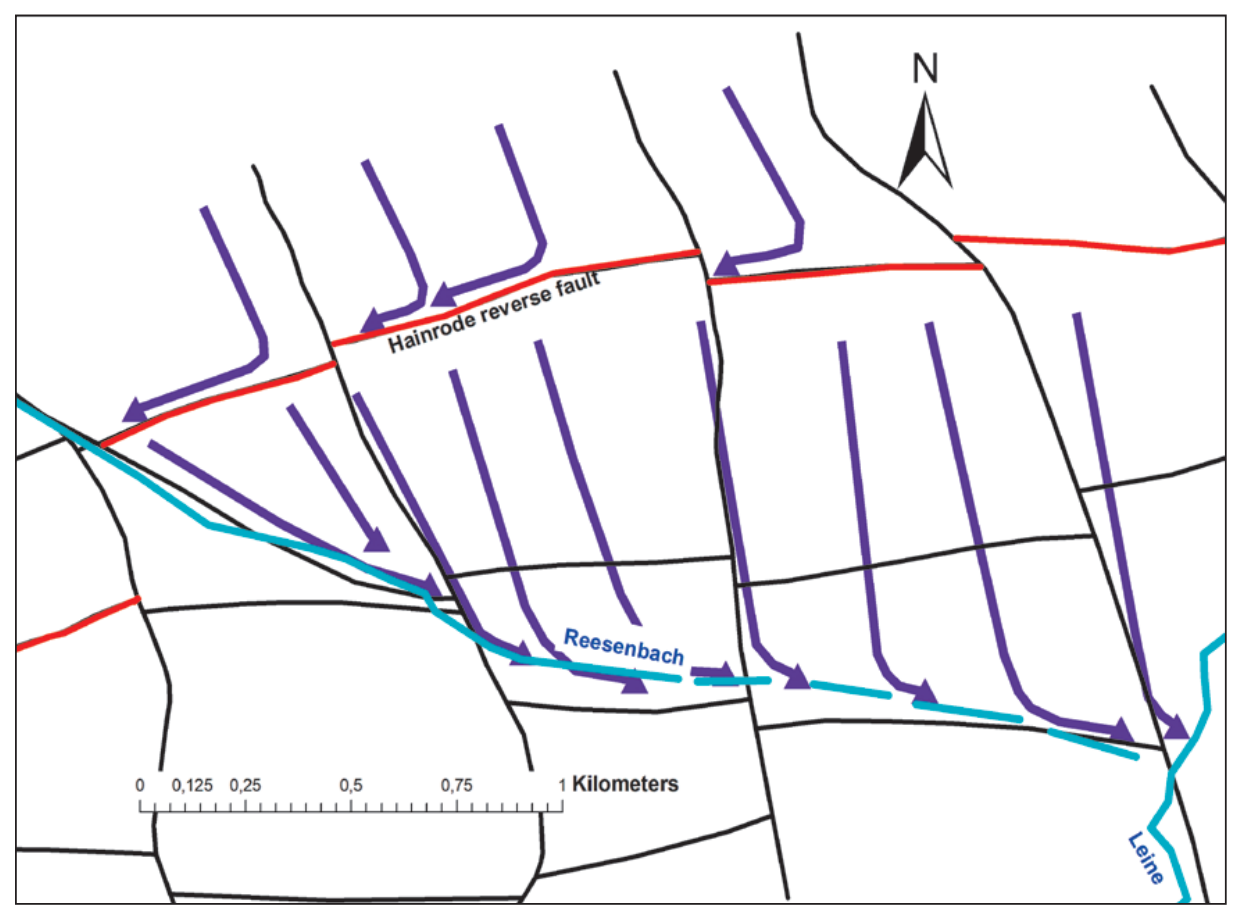

Fig. 18: Sketch of groundwater flow along the Hainrode reverse fault. 


\section{CONCLUSIONS}

So far, the South Harz Zechstein sulfate karst has not been looked at from a unified perspective. This was not only due to the German division in East and West, but also to the fact that no standardized geological map and no overall tectonic model existed. With the doctoral thesis by the first author (Hubrich 2020) the situation changed. In evaluating numerous new geological field surveys plus the published old (partly older than 100 years) geological Quadrants $(1: 25,000)$ a digital geological map was constructed with the modern division into three evaporative cycles (the fourth cycle is present as well but is only rarely exposed). Since the area is covered to $43 \%$ by Quaternary deposits (river terraces, loess and remains of the Elsterian tillite), the tectonic interpretation had to rely on those areas that could be mapped at a high resolution $(1: 10,000)$. The overall assumption was that the Zechstein-series was tilted by several degrees southward due to the tilting of Harz mountains during the Upper Cretaceous. Mapping showed that much of the area is affected by South Harz-parallel (in the widest sense "hercynian") reverse faulting, explaining the variously wide outcrop area of the Zechstein. Without these faults, the Zechstein belt would rarely exceed $1 \mathrm{~km}$ in width despite varying thicknesses of the strata. Additionally, the terrain is structured in horst and graben tectonics. For example, a graben in which overlying Buntsandstein is preserved can be followed for many kilometers north of Nordhausen. Later, dilatational forces produced "rhenian" (in the widest sense) graben features, perpendicular to the E-W striking belt. The conclusion that such a model is valid is substantiated by the profile across the Sangerhausen Basin obtained by copper-shale mining (Fig. 4), showing that the Zechstein is uplifted many times along normal and reverse faults. Otherwise the copper-shale mining would have had to operate at depths well below $1000 \mathrm{~m}$.

It is understood that the derived pattern of faults is a model and that in many areas the exact location and number of faults may be up to discussion. The problem at hand is like solving an equation with three unknowns, inclination, thickness and faulting with only knowing surface geology and geomorphology. However, the reconstruction not only shows internal consistency, it also is embedded into the larger tectonic history of Central Europe and it can explain prominent features of the karst hydrology and morphology. Specifically, E-W striking faults play an important role. Within the stack of Zechstein evaporites, only the carbonate layers $\mathbf{z 1 K}$ and $\mathbf{z 2 K}$ are - due to their layering and jointing - natural aquifers. Through these layers water can flow south following the general inclination of the strata. When arriving at a revers fault, it would encounter impervious rocks of the underlying silty or clayey and/or folded Pre-Zechstein formations. Thus, the water is diverted from a southern to an E-W directed flow, potentially feeding springs along cross-cutting N-S valleys. The most prominent of such springs is the Salza Spring near Förste. In case of the Rhume Spring and the Salza Spring at Nordhausen, downfaulted Lower Buntsandstein creates the condition for an overflow spring. However, the water arriving at these points must have been directed there by N-S crosscutting faults, undoing the importance of south lifting faults. This is especially true for the Nordhausen Salza Spring where several faults seem to converge, guiding water sinking in several creeks to this spring location.

Not all the water sinking is necessarily reappearing in karstic springs. Some of the water, such as that sinking in the Nixsee basin, seems to disappear in the deeper karstic underground below the Buntsandstein. In contrast to these deeply circulating waters, the South Harz Karst has also developed shallow karstic systems, such as that of the Beierstein, Hainholz and Trogstein. These are also depending on tectonics.

Much is still to be learnt about the South Harz karst systems. Modern methods as for example helium isotopy or noble gas concentrations could help to understand deep karstic systems. Also, there are still many sinks that have never been studied by water tracing as to their reappearances.

\section{ACKNOWLEDGEMENTS}

The authors are highly indebted to the numerous students that scouted the area during mapping courses and during their Diploma, Master and Bachelor theses. Over the years discussions with many colleagues promoted the project, too many to be listed here with the chance to miss somebody that should be thanked. Christel and Reiner Völker kindly made their sinkhole cadaster and the speleologists from the Arbeitsgemeinschaft für Karstkunde, Harz, made their cave surveys available to the authors. Our librarian, Petra Kraft, helped in getting theses and literature. The Nature Preserve Administrations granted access to protected sites. Furthermore, suggestions of an unknown reviewer helped to improve the presentation. 


\section{REFERENCES}

Behrens, G.H., 1703: Hercynia Curiosa oder Curiöser Hartz-Wald.- Carl Christian Neuenhahn, pp. 200+16, Nordhausen.

Biese, W., 1931: Über Höhlenbildung, 1. Teil, Entstehung der Gipshöhlen am südlichen Harzrand und am Kyffhäuser.- Abh. Preuß. Geol. Landesanst, Neue Folge, 137, pp. 71.

Böttcher, M.E. \& I. Rienäcker, 1990: Hydrogeochemische und isotopenchemische Untersuchungen an Grund- und Oberflächenwässern am Südwestrand des Harzes während eines künstlich induzierten Hochwassers.- Z. Wasser- Abwasser-Forsch., 23, 136-140.

Brandt, A., Kempe, S., Seeger, M. \& F. Vladi, 1976: Geochemie, Hydrographie und Morphogenese des Gipskarstgebietes von Düna/Südharz.- Geol. Jb., C $15,3-55$.

Brust, M.K., 2008: Die „Mansfeldischen Kalkschlotten“ und ihre Bedeutung für den historischen Kupferschieferbergbau.- Exkurs. Führer u. Veröffentl. Deut. Geol. Ges., 235, 10-18.

Brust, M.K. \& J. Graf, 2016: Die Schlotte auf dem SegenGottes-Stollen und die Elisabethschächter Schlotte, zwei touristisch zugängliche Höhlen im Gipskarst (Landkreis Mansfeld-Südharz, Sachsen-Anhalt).Grubenarchäologische Gesellschaft e.V., online $\mathrm{Pu}$ blikationen, pp. 13. [Online] Available from: https:// untertage.com/downloads/Brust_et_Graf_2016_ Die_Schlotte_auf_dem_Segen-Gottes-Stollen_etc. pdf [Accessed June 29 $9^{\text {th }}$ 2020].

Carlé, W., 1955: Bau und Entwicklung der Südwestdeutschen Großscholle.- Beih. Geol. Jb., 16, 272 S 4 T, 45 Abb.

Cohen, K.M., Finney, S.C., Gibbard, P.L. \& J.-X. Fan, 2018: The ICS International Chronostratigraphic Chart.- Episodes, 36, 199-204. DOI: 10.18814/epiiugs/2013/v36i3/002

Flindt, S., 2004: Die Lichtensteinhöhle. 10 Jahre Forschung unter Tage.- In: Fansa, M., Both, F. \& H. Hassmann (eds.): Archäologie Land Niedersachsen, 400.000 Jahre Geschichte.- Landesmuseum für Natur und Mensch, pp. 688, Oldenburg.

Freiesleben, J.C., 1809: Geognostische Arbeiten.- Craz und Gerlach, Freiberg, Vol. 2, 160-191.

Frickenstein, R. \& A. Wunsch, 1966: Über die Tiefe der Rhumequelle im Südharz.- Mitt. Verbd. dt. Höhlenu. Karstforscher, 12, 4, 98-100.

Geologisches Landesamt Sachsen-Anhalt in Kooperation mit dem Niedersächsisches Landesamt für Bodenforschung, 1998: Geologische Karte Harz 1: 100 000.- Geol. Landesamt Sachsen-Anhalt, Halle.
Haase, H., 1936: Hydrologische Verhältnisse im Versickerungsgebiet des Südharz-Vorlandes.- Dissertation, Georg-August Universität zu Göttingen, pp. 218.

Haase, H., 1958: Neue Forschungsergebnisse von der Rhumequelle.- Heimat-Kalender des Kreises Osterode und des Südwestrandes des Harzes, Osterode/Harz, Giebel und Oelschlägel, 36-41.

Haase, H., 1962: Von den Salzquellen in Förste.- Heimatkalender für den Landkreis Osterode am Harz.

Heinsen, E. \& H. Haase, 1961: Gutachten über die Herkunft des Mineralwassers in den Förster Salzquellen zu Förste, Kr. Osterode (Harz).- Mscr., 14 Anl. pp. 36, Osterode am Harz (unpubl.).

Herrmann, A., 1956: Der Zechstein am südwestlichen Harzrand (seine Stratigraphie, Fazies, Paläogeografie und Tektonik).- Geol. Jb., 72, 1-72.

Herrmann, A., 1964: Gips- und Anhydritvorkommen in Nordwestdeutschland.- Silikat J., 3, 6, 442-466.

Herrmann, A., 1969a: Einführung in die Geologie, Morphologie und Hydrogeologie des Gipskarstgebietes am südwestlichen Harzrand.- Jh. Karst- u. Höhlenkunde, 9, 1-10.

Herrmann, A., 1969b: Die geologische und hydrologische Situation der Rhumequelle am Südharz.- Jh. Karst- u. Höhlenkunde, 9, 107-112.

Herrmann, A., 1981a: Eine neue geologische Karte des Hainholzes bei Düna/Osterode am Harz.- Ber. Naturhist. Ges. Hannover, 124, 17-33.

Herrmann, A., 1981b: Zum Gipskarst am südwestlichen und südlichen Harzrand.- Ber. naturhist. Ges. Hannover, 124, 35-45.

Herrmann, A. \& G. Richter-Bernburg, 1955: Frühdiagenetische Störungen der Schichtung und Lagerung im Werra-Anhydrit (Zechstein) am Südwestharz.Z. dt. geol. Ges., 105, 689-702.

Hintze, C., Jordan, H. with contribution by Friedrich, H. v. \& P. Meiser, 1981: Die Westrandstörung des Harzes.- Z. dt. geol. Ges., 132, 17-28.

Hubrich, H.-P., 2020: Aufklärung der tektonischen Struktur des Harz-Südrandes und dessen Genese seit dem Perm durch Erfassung der Geologie des Südharzer Zechsteins im Maßstab 1:10,000.- Dissertation TUDarmstadt, in preparation.

Jordan, H. (ed.), 1976: Geologische Karte Niedersachsen 1:25 000 und Erläuterungen zu Blatt Osterode Nr. 4227.- Niedersächsisches Landesamt für Bodenforschung, 5 maps, pp. 148, Hannover.

Jordan, H., 1979: Der Zechstein zwischen Osterode und Duderstadt (südliches Harzvorland).- Z. dt. geol. Ges., 130, 145-163.

Kempe, S., 1982: Long-term records of $\mathrm{CO}_{2}$ pressure fluc- 
tuations in fresh waters.- Habilitationsschrift. In: Degens E.T. (ed.) Transport of Carbon and Minerals in Major World Rivers, Pt. 1, Mitt. Geol.-Paläont. Inst. Univ. Hamburg, SCOPE/UNEP Sonderband, 52, 91-332.

Kempe, S., 1996: Gypsum karst of Germany.- In: Klimchouk, A., D. Lowe, A. Cooper \& U. Sauro (eds.) Gypsum Karst of the World, Intern. J. Speleol. Spec. Issue Vol., 25, 3-4, 209-224.

Kempe, S., 2014: How deep is hypogene? Gypsum caves in the South Harz.- In: Klimchouk, A., Sasowsky, I.D., Mylroie, J., Engel, S.A., \& Engel, A.S. (eds.) Hypogene Cave Morphologies, Karst Waters Inst. Spec. Publ., 18, Proc. San Salvador, Bahamas Feb. 2-7, 2014, 57-64.

Kempe, S., 2019: Die Sedimente der Jettenhöhle im NSG Gipskarstlandschaft Hainholz bei Düna im Südharz.- Mitt. Verbd.. Dt. Höhlen- u. Karstforscher, $65,1+2,11-18$.

Kempe, S. \& K. Emeis, 1979: Geschichte einer Schlotte im Naturschutzgebiet Hainholz/Südharz.- Heimatblätter für den Südwestlichen Harzrand, 35, 63-74.

Kempe, S. \& A. Helbing, 2000: Die "Größe" deutscher Gipshöhlen.- Die Höhle, 51, 1, 13-20.

Kempe, S. \& F. Vladi, 1988: Die Lichtenstein-Höhle, eine präholozäne Gerinnehöhle im Gips und Stätte urgeschichtlicher Menschenopfer am Südwestrand des Harzes (Gemarkung Dorste, Landkreis Osterode am Harz).- Heimatbl. für den süd-westl. Harzrand, $44,1-12$.

Kempe, S. \& F. Vladi, 2019: Archäologische Ausgrabung Lichtensteinhöhle: Kap. 2.2 Geologie und Speläogenese.- In: Flindt, S. (ed.), Lichtensteinhöhle, submitted.

Kempe, S., Seeger, M. \& F. Vladi, 1970: Geologische Kartierung des Gipskarstes im Bereich Hainholz und Beierstein bei Düna/Südharz.- Mscr. Hamburg, pp. 24 (unpub.).

Kempe, S., Mattern, E., Reinboth, F., Seeger, M. \& F. Vladi, 1972: Die Jettenhöhle bei Düna und ihre Umgebung.- Abh. Karst- u. Höhlenkunde A6, pp. 63.

Kley, J., 2013: Saxonische Tektonik im 21. Jahrhundert.Zeitschrift Deutsche Gesellschaft für Geowissenschaften, 164, 2, 295-311. DOI: 10.1127/1869$1804 / 2013 / 0022$

Kley, J. \& T. Voigt, 2008: Late Cretaceous intraplate thrusting in Central Europe, Effect of Africa-Europe convergence, not Alpine collision.- Geology, 36, 11, 839-842. DOI: 10.1130/G24930A.1

Kuhn, O., 1964: Die Tierwelt des Mansfelder Kupferschiefers.- Die neue Brehm Bücherei, A. Ziemen Verlag, Wittenberg, pp. 58.

Kulick, J. \& J. Paul (eds.), 1987: International Symposium
Zechstein 1989, Kassel, Hannover, 2 Bd. Exkursionsführer.- Wiesbaden, pp. 173+310.

Kupetz, M. \& M. Brust, 1991: Historisches zum Begriff der „Mansfelder Kalkschlotten“ sowie ein Beitrag zur nomenklatorischen Bestimmung dieses Höhlentyps.- Mitt. Arbeitsgemeinschaft Karstkunde Harz, 1, 10-35.

Kupetz, M. \& F. Knolle, 2015: Die Mansfelder Schlotten - Verbreitung und Genese der größten mitteleuropäischen Anhydrit-Schichtgrenzhöhlen.- Z. Dt. Ges. Geowiss., 166, 4, 327-339. DOI: 10.1127/ zdgg/2015/0037

LBEG, 2002: Landesamt für Bergbau, Energie und Geologie, Symbolschlüssel Geologie.- Hannover, accessed 11/2002.

Liersch, K.-M., 1988: Zur Wasserbilanz der Rhumequelle und ihres Einzugsgebietes, des Pöhler Beckens.Neues Archiv für Niedersachsen, 36, 3, 293-305.

Mignat, A., 1984: Strukturgeologische Untersuchungen im Karstgebiet des Hainholzes bei Düna/ SW-Harz.- Diplomarbeit, Clausthal, pp. 84 (unpublished).

Menning, M., 1995: A numerical time scale for the Permian and Triassic periods: an integrated time analysis.- In: Scholle, P.A., Peryt, T.M. \& D.S. UlmerScholle (eds.) The Permian Northern Pangea, Vol. 1. Springer Verlag, Berlin, 77-97.

Paul, J., 1987: Der Zechstein am Harzrand: Querprofil über eine permische Schwelle, Stop 1-23.- In: Kulick, J. \& J. Paul (eds.) International Symposium Zechstein 1989, Kassel, Hannover, 2. Bd. Exkursionsführer, Wiesbaden, 193-276.

Paul, J., 2014: Gypsum domes and diapirs - common features of Zechstein evaporites (Upper Permian) in Germany.- Geological Quarterly, 57, 463-472. DOI: 10.7306/gq.1192

Paul, J., 2016: Diapirismus und Doming von Sulfatgesteinen (Zechstein, Harz).- In: Friedel C.H. \& B. Leiss (eds.) Harzgeologie 16; 5. Workshop Harzgeologie.- Göttinger Contr. Geosci., 78, 37-39. DOI: 10.3249/978-3-86395-292-1

Paul, J., Quast, A., Ahlborn, F., Plache, M. \& R. Reh, 1998: Geologie des Gipskarstgebietes zwischen Nordhausen und Stempeda (Zechstein, südlicher Harzrand).- Geowissen. Mitt. von Thüringen, 6, 57-81.

Priesnitz, K., 1969a: Kurze Übersicht über den Karstformenschatz des südwestlichen Harzrandes.- Jh. Karst- u. Höhlenkunde, 9, 11-24.

Priesnitz, K., 1969b: Das Nixseebecken, ein Polje im Gipskarst des südwestlichen Harzvorlandes.- Jh. Karst- u. Höhlenkunde 9, 73-82.

Reinboth, F., 1969: Die große Trogsteinhöhle im Harz als Beispiel einer Schichtgrenzhöhle im Gips.- Mitt. 
Verband dt. Höhlen- u. Karstforscher, 15, 3-4, 3743.

Richter-Bernburg, G., 1955: Stratigraphische Gliederung des deutschen Zechsteins.- Z. dt. geol. Ges., 105, 843-854.

Röhling, H.-G., 2004: Infoblatt zum bundesweiten Tag des Geotops 2004, Der Römerstein nördlich von Nüxei.- Niedersächsisches Landesamt für Bodenforschung, Hannover.

Scholle, P.A., Peryt, T.M. \& D.S. Ulmer-Scholle (eds.) 1995: The Permian Northern Pangea, 2 Vols.- Springer Verlag, Berlin, pp. 261 and 312.

Schriel, W. \& K. v. Bülow, 1926: Geologische Karte 1:25,000 Blatt 4532. Kelbra, und Erläuterungen.Preuss. Geol. Landesanst., Berlin, pp. 55.

Schriel, W. \& R. v. Gaertner, 1930: Geologische Karte 1:25,000 Blatt 4430, Nordhausen-Nord.- Preuss. Geol. Landesanst., Berlin.

Seidel, G., 1974: Kapitel 4.4.2 Zechstein.- In: Hoppe, W. \& G. Seidel (eds.) Geologie von Thüringen, Hermann Haack, Geographisch-Kartographische Anstalt Gotha/Leipzig, 516-553.

Stedingk, K., Herold. U. \& J. Heckner, 2006: Kupferschieferbergbau und Gipskarst am Südharz.- Jber. Mitt. oberrhein. geol. Ver., N.F., 8, 345-368.

Stolberg, F., 1926: Die Höhlen des Harzes. Bd. 1 Einleitung und Südharzer Zechsteinhöhlen.- Sonderausg. „Der Harz" Heft II, pp. 40.

Stolberg, F., 1943: Die Mansfelder Schlotten.- Z. f. Karstu. Höhlenkunde, 42-43, 11-35.

Vladi, F., 2004: Zur Geologie der Einhornhöhle, Südharz.- Mitt. Verb. dt. Höhlen- u. Karstforscer, 50, 2, 44-51.
Völker, R. 1981: Die Heimkehle.- Mitt. Karstmuseum Heimkehle, Heft 1, 40 pp.

Völker, R. \& C. Völker, without year, ca. 1982: Die Elisabethschächter Schlotte.- Mitt. Karstmuseum Heimkehle, Heft 2, pp. 24.

Völker, R. \& C. Völker, 1983: Die Segen Gottes Schlotte.Mitt. Karstmuseum Heimkehle, Heft 3, pp. 15.

Völker, C. \& R. Völker, without year, ca. 1984: Auf dem Weg in die Elisabethschächter Schlotte.- Mitt. Karstmuseum Heimkehle, Heft 11, pp. 41.

Völker, C. \& R. Völker, 1986: Die Wimmelburger Schlotte.- Mitt. Karstmuseum Heimkehle, Heft 13, pp. 60.

Völker C. \& R. Völker, 2016: Der Salzaspring.- Private printing, Uftrungen, pp. 18.

Völker C. \& R. Völker, 2017: Historische Schlottenforschung.- Mitt. Arge f. Karstkunde Harz, 38, 3-4, $3-49$.

Völker, C. \& R. Völker, 2019: Eine Wanderung durch die Karstlandschaft zwischen Wettelrode und der Heimkehle.- Private printing, Uftrungen, pp. 37.

Williams-Stroud, S. \& J. Paul, 1997: Initiation and growth of gypsum piercement structures in the Zechstein Basin.- J. Struct. Geol., 19, 7, 897-907. DOI: 10.1016/S0191-8141(97)00017-5

Wrede, V., 1979: Beobachtungen zum tektonischen Bau des N-Harzrandes bei Goslar.- Der Aufschluss, 30, 253-265.

Wrede, V., 1988: Der nördliche Harzrand - flache Abscherbahn oder wrench-fault-system?- Geologische Rundschau, 77, 1, 101-114. 